\title{
The Yale Law Journal
}

Volume 79, Number 1, November 1969

\section{Mr. Taft Rehabilitates the Court}

\section{Alexander M. Bickel $\uparrow$}

Mr. Justice David Josiah Brewer died in March, 1910, after twenty years of service on the Supreme Court. On May 31, 1910, in accordance with a custom almost uniformly observed, there were proceedings in his memory in open court. ${ }^{1}$ It was the last day of the October Term, 1909. Chief Justice Melville W. Fuller, who had preceded Brewer on the bench by no more than a year and a half, opened his response to a eulogy by Attorney General George W. Wickersham as follows:

During the years of my occupancy of a seat upon this Bench it has been my sad duty to accept for the Court tributes of the Bar in memory of many members of this tribunal who have passed to their reward. As our brother Brewer joins the great procession, there pass before me the forms of Matthews and Miller, of Field and Bradley and Lamar and Blatchford, of Jackson and Gray and of Peckham, whose works follow them now that they rest from their labors. ${ }^{2}$

All excellent, illustrious men, though quite different from each other, Fuller continued. Very briefly he dwelt on Brewer, "one of the most lovable of them all," on death and the hereafter, on Brewer's eloquence and on his humor, which, like Mr. Lincoln's, served to lighten the load.

And so Fuller ended. It was the last time he sat, and these were virtually his last words spoken from the bench, for he had no substantial opinion to deliver that day. Before the beginning of the next Term, Fuller died, aged 77, in Sorrento, in his native Maine, on Independence Day, 1910. Less than a year earlier, Peckham ${ }^{3}$ had gone. Moody, 4 quite ill for the past Term, retired shortly thereafter and

+ Chancellor Kent Professor of Law and Legal History, Yale University. BSS. 1947, C.C.N.Y.; LL.B. 1949, Harvard University. This article is an outgrowth of studies undertaken by the author for a volume of the History of the Supreme Court now in preparation.

1. 218 U.S. vii (1910).

2. Id.

9. Rufus W. Peckham, Associate Justice of the Supreme Court, 1896-1909.

4. William Henry Moody, Associate Justice of the Supreme Court, 1906-1910. 
soon also died. Harlan, ${ }^{5}$ in his thirty-third year of service, had but one more to go. By 1912, five men were on the Court who had not been there in 1909-Lurton, Hughes, Van Devanter, Joseph Lamar and Pitney, a new majority under a new Chief Justice.

It is tempting to hold that Fuller's emotional evocation of the men he had served with marks the end of an era. The temptation is the stronger as one can marshal other indicia of change. Fuller was fourth in succession to John Marshall-a total of five Chief Justices from 1801 to 1910. Of these Marshall served thirty-four years; Taney, twentyeight; Fuller himself, over twenty-one. Fuller's predecessor, Waite, sat for only fourteen years, and before him there was a brief, troubled interlude of Chase. Yet it signifies in the history of the Court and it affected the character of the institution that for eighty-four years just three men sat as Chief Justice. The era that opened in 1910 was to be quite different. Fuller's successor, White, though a side-judge for sixteen years, was Chief Justice for a mere ten and a half. He was followed by Taft for eight, Hughes eleven, Stone less than five, Vinson seven. The next substantial tenure after Fuller's was that of Earl Warren, beginning in 1953. Again, White's was the first appointment of a Chief Justice from within the Court. Stone's appointment in 1941 was to provide the only like instance.

The year 1910 marked also something of a turning point in the political history of the country. It was a year of Republican insurgency in Congress, the year when, for the first time in eight elections, a Democratic House of Representatives was sent to Washington, the year of Theodore Roosevelt's decisive turn to progressive agitation; the year, in short, of "one of those significant divides in American history which signalize a reversal in political trends before a complete transfer of power occurs." 6

And yet, as we shall see, there was no significant divide in the his. tory of the Supreme Court. The single appointment of Brandeis in 1916 more nearly qualifies for such a description, as do the appointments made by Harding in 1921 and 1922. Brandeis was a new man, of an entirely different cast from that of the colleagues he joined, different in experience and outlook, the first of many new men who were to constitute the Court a generation hence, and perhaps the single most powerful judicial influence on them. Harding's appointment of Sutherland and Butler, both rigidly committed conservatives, created

5. John Marshall Harlan, Associate Justice of the Supreme Court, 1877-1911.

6. G. Mowry, The ERA of Theodore RoOsevelt 272 (1958). 
an almost unvarying majority, which set the institution firmly on one of the several courses it had been pursuing. And this was the course that led, in essential attitudes if not in all niceties of doctrine, to the struggle of 1937, and to the veritable revolution that followed.

The five appointments made by President Taft in the three years from 1909 to 1912 had no such effect. Neither attitude nor doctrine was to harden for another decade. Both remained more or less ambivalent under White. If there was a movement away from such unpopular decisions as Lochner v. New York and The First Employers Liability Cases, ${ }^{8}$ the movement was as far from being radical as it was from being permanent, it did not involve a firm settlement of doctrine, and it proceeded from other precedents that had grown up more quietly alongside these highly notorious cases; it was, indeed, a movement not away, but alongside. ${ }^{9}$

The William Howard Taft who in 1922, as Chief Justice, heartily welcomed the appointment of Sutherland and actively sought the appointment of Butler was in some measure a different man and, what is more important, a man acting in different political circumstances and from different motives than the President of 1910. The Taft of 1922 viewed conservative Republican principles as being at once happily ascendant in the White House and dangerously menaced within the Court. This was the Court, after all, on which sat a Brandeis, boring from within, as Taft sometimes was wont to say, and a Holmes whom Taft, in common with the rest of the country, perceived rather differently now than he had a decade earlier. Taft was, therefore, quite clear in 1921-22 and to the end of his life that only men whom he could trust as sound, men of definite, ascertainable conservative principles should be appointed. Each appointment had to be utterly safe. Even a Henry L. Stimson, let alone a Cardozo or a Learned Hand, seemed to Taft at this time a dubious risk. ${ }^{10}$ But Taft the President of 1910 gave scarcely a thought to the danger that the Court's conservative soundness might be impaired from within. If anything, he shared the general regret about some conservative excesses of the past, and he was certainly not yet entirely free of the dominating influence of Theodore Roosevelt. It was the election of

7. 198 US. 45 (1905).

8. 207 U.S. 463 (1908).

9. See C. Warren, The Progressiveness of the United States Supreme Court, 13 Colus. L. REv. 294 (1913).

10. W.H. Taft to W.G. Harding, Dec. 4, 1922; Taft to Elihu Root, Dec. 21, 1922; Taft to C.D. Hilles, Dec. 31, 1922, TV.H. Taft Papers, Library of Congress [hercinafter cited as Taft Papers]. 
1912, says his biographer, that heightened in Taft "the conservatism he had shaken off under the influence of Roosevelt."11

Soundness, in 1910, therefore, meant men of balance; conservatives, to be sure, but men of moderation. So long as a candidate was a substantial and successful lawyer and politician, and certainly if he was a sitting federal judge, there was little need to inquire with precision and in detail into the principles he held, for there was no danger within the Court, and hence no requirement of strict conformity. It might actually strengthen the Court and shore up public confidence in it if the President were to appoint one or two men who, while sound, substantial and well established in the profession, were of relatively progressive reputation; and it was certainly a good thing to have an occasional Democrat, provided he qualified as a lawyer of standing, which would automatically ensure that he was respectable and free of any taint of Populism. As late as the summer of 1912, when selecting a district judge, Taft remarked that

the times are out of joint and it is exceedingly important that ... we should not only have men who can administer justice and who know the law, but that we should also have men of sufficient knowledge of affairs not to involve the Court in unnecessary controversy and to retain among the people as great a respect and friendship for it as possible, consistent with its administering proper justice. ${ }^{12}$

Some years later, in July, 1923, Brandeis reported a conversationone of the warmest, he said; in fact, the only near-heated one-he had had with Chief Justice Taft the previous fall. Taft asked Brandeis to suggest possible Democrats for appointment to the Court. Brandeis replied that he didn't believe in appointing men as Democrats or Republicans. Those were not, he said, the lines of cleavage on the Court, and it was wrong to encourage a belief on the part of the public that the Court divided along such lines. The actual differences of opinion among the Justices turned on "progressiveness, so-called-views as to property." Taft replied that he disagreed altogether. "We can't go around looking for men with certain creeds on property." And he brought up his appointments of Democrats in 1909-10. "Don't you think I did a good thing?" Brandeis lowered the temperature by answering that times were different then, and thus apparently ended the conversation. But he believed that Taft was, in fact, hunting for

11. 2 H. Pringle, The Life and Times of William Howard Taft 841 (1939).

12. Taft to O.W. Holmes et al., Aug. 3, 1912, Taft Papers. 
men "with certain creeds on property." And in appointing Democrats when he was President, Taft had not done a particularly good thing, Brandeis believed, and the men he had appointed "did have certain views on property: White, Lamar, Lurton."13

The truth is that Taft was being disingenuous with Brandeis in the fall of 1922, when he surely was looking hard for safe and sound property men. But Brandeis was unjustly identifying the Taft he knew, who had after all undergone the shock of Brandeis' own appointment, with the President of more than a decade before. Times were different then, they were differently "out of joint." It can be said of President Taft that he made no effort at all to look for the sort of judges Theodore Roosevelt had insisted on finding. "You know how anxious I am," Roosevelt wrote in 1907 to Justice Moody, his former Attorney General, "to get a man who shall not only be an honest man and a good lawyer, but a liberal-minded man, a man with sympathy for the position of labor . . . a man who is not to be scared by technicalities from exercising the proper control over corporations. . . ."14 Roosevelt was then looking for a Circuit Judge, but this is also how he had tried to pick his Supreme Court nominees, notably Holmes. ${ }^{15}$ This was not how President Taft picked. He had no mission to reform the judicinry. An "honest man and a good lawyer;" professional competence and standing, vigor and effectiveness, and conventional political considerations such as geographic distribution and party representation-these were President Taft's decisive criteria. The rest-"certain creeds on property"- - would take care of itself.

Moreover, it was, perhaps, Taft's overriding concern, not excluded in 1922, either, but felt more keenly in 1910, to equip the Court with active men of middle years who could carry the load. For the Court was in a bad way, and needed to be reconstituted. As early as May, 1909, Taft wrote to Horace H. Lurton, his good friend, then still a Circuit Judge:

The condition of the Supreme Court is pitiable, and yet those old fools hold on with a tenacity that is most discouraging. Really the Chief Justice is almost senile; Harlan does no work; Brewer is so deaf that he cannot hear and has got beyond the point of the commonest accuracy in writing his opinions; Brewer and

13. Brandeis-Frankfurter Conversations (Harvard Law School Library).

14. Theodore Roosevelt to W.H. Moody, June 5, 1907, Ietter in possession of author.

15. See D. McHargue, Appointments to the Supreme Court of the United States 344-50, 1949 (unpublished dissertation, University of California at Los Angeles); W. HanDauci, POWER AND RESPONSIBILITY 163 (1961). 
Harlan sleep almost through all the arguments. I don't know what can be done. It is most discouraging to the active men on the bench. ${ }^{16}$

Meanwhile Justice Moody was succumbing to his disabling illness, and on September 2, 1909, before the opening of the October Term 1910, at which Moody would not sit, Taft complained further to Senator Henry Cabot Lodge:

It is an outrage that the four men on the bench who are over seventy should continue there and thus throw the work and responsibility on the other five. This is the occasion of Moody's illness. It is with difficulty that I can restrain myself from making such a statement in my annual message. ${ }^{17}$

As the October Term 1909 opened, Peckham also was absent. He was ill, and it was not clear how gravely. Attorney General George W. Wickersham reported to the President that Justice White had urged him not to bring any important case before the Court while it was in its present state. ${ }^{18}$

Within the month, the situation cleared somewhat. On October 24, 1909, Peckham died, and Taft had his first chance to make an appointment. His choice was his old friend and colleague on the bench of the Circuit Court for the 6th Circuit, Horace H. Lurton. "It is just the simple truth to tell you," Taft wrote Lurton after making the appointment, "that the chief pleasure of my administration, as I have contemplated it in the past, has been to commission you a Justice of the Supreme Court; and I never had any other purpose ...."10 Taft supported Lurton's candidacy in 1906 for the vacancy to which Moody was eventually appointed, this being a candidacy that foundered on the partisan rock of Senator Henry Cabot Lodge. "My objection," wrote Lodge to President Roosevelt, "is fundamental. I do not think that you ought to appoint a Democrat to the Supreme Court."20 Now, in 1909, there was some misgiving on the part of Samuel Gompers, which Taft dismissed, not as he might have done in 1922, on the ground that it served to confirm the soundness of the appointment, but rather because these ideological objections did not seem very relevant. Taft

16. Quoted in 1 PRINGLE, stupra note 11 , at 529.30.

17. Quoted in id.

18. G.W. Wickersham to Taft, Oct. 18, 1909, Taft Papers (two letters).

19. Taft to H.H. Lurton, Dec. 26, 1909, Lurton Papers, Library of Congress [hercinafter cited as Lurton Papers].

20. H.C. Lodge to Roosevelt, Sept. 1, 1906, T. Roosevelt Papers, Library of Congres4 [hereinafter cited as Roosevelt Papers]; see 5 LeTrers of THeodore Rooseveir 896 (E. Morrison \& J. Blum eds. 1951); cf. Taft to Roosevelt, Sept. 8, 1906, Roosevelt Papers. 
knew Lurton to be a just man, and as liberal-minded, he said, as anyone.21 The difficulty, and there was a difficulty, highlighted Taft's chief concern-putting vigorous, effective men on a Court that sadly lacked them. The difficulty was that Lurton was sixty-five. "For this reason," as Taft wrote Lurton after he appointed him, "I took back my determination to appoint you, wiped it off the slate, and gave two or three days to the introspective process to know whether I was yielding to personal preference and affection at the expense of the public. I became convinced that I was not ... that I have the right to gratify my personal predilection by doing what I have done, because the motive in doing it included a desire to strengthen that Court as much as I could strengthen it." 22

So it was that President Taft, himself much less ideologically committed than he was later to become, seeking still to occupy the middle ground in politics and not free of reelection worries, cherishing the institution as his predecessor had not, and seeing that it suffered more from old age and incompetence than from grave ideological division within, anxious to make it effective and enhance its professional prestige-a President thus relatively little intent on a candidate's precise ideological orientation, although in three short years he appointed a whole new majority, left the Court pretty much unchanged. For this ambiguous achievement, he received an ambiguous reward when, at a dinner in his honor in January, 1911, Joseph $\mathrm{H}$. Choate, the most ac. complished toastmaster and one of the most famous advocates at the American Bar, told him: "Mr. Taft has rehabilitated the Supreme Court of the United States. We will now be able to know what the law means and what the law is." ${ }^{23}$ And there was lasting inner satisfaction. On going out of office, Taft told newspapermen that the achievement in which he took greatest pride was the reconstitution of the Court. He had said to his appointees, Taft remarked: "Damn you, if any of you die, I'll disown you." 24

When Brewer died on March 28, 1910, President Taft did not suffer much doubt about a replacement. He seems almost to have had his choice prepared in advance, and within a month he made the appointment. The week before Brewer's death, Taft had been to Albany, where he had a long talk with Governor Charles Evans Hughes of

21. S. Gompers to Taft, Dec. 1909, Taft Papers; see 1 Prixicle, supra note 11, at 531.

22. Taft to Lurton, supra note 19.

23. Quoted in M. KeLLER, IN DEFENSE OF Yesterday 89 (1958).

24. See 2 Pringle, supra note 11 , at 853.54. 
New York, and spent the night at the Executive Mansion. ${ }^{25}$ Hughes, born in Glens Falls, N.Y., on April 11, 1862, was, at 48, a nationally known, successful if embattled reform governor. The son of an immigrant Welsh Baptist minister, Hughes attended Colgate University, then Brown, where he received a bachelor's degree, then Columbia Law School for an LL.B. He practiced law in New York and married Antoinette Carter, daughter of his senior partner. Later he taught law briefly at Cornell. Hughes entered public life early in 1905 as counsel to a committee of the New York legislature investigating the gas and electric utilities. In the fall of that year, he conducted an even more celebrated investigation of the life insurance business, which propelled him into the governorship in the election of 1906. In 1908, he was a serious, although undeclared, possibility for the Republican Presidential nomination which Theodore Roosevelt awarded to Taft. Hughes declined the Vice Presidential nomination. ${ }^{20}$

As Taft visited him in Albany in 1910, Hughes was in the last year of his second term as governor. He was, at this time of life, under considerable inner tension, and easily subject to nervous strain. But, impeccably attired, his beard well brushed, if, perhaps, a little longer than it was later remembered, he cut a vigorous, resolute, altogether imposing public figure. He had already acquired the reputation for stiffness-undeserved, his biographer thinks, ${ }^{27}$ and belied by the private personality-which was to remain with him for the rest of his days, but he enjoyed also a reputation for formidable rectitude.

The question of a third two-year term as governor faced Hughes in March of 1910, and he made it clear to Taft that he had no wish to continue in the office. "I do not dare to run the chance of breaking down mentally," Taft's aide, Captain Archie Butt, who accompanied the President, reports Hughes as saying. He had had warnings from his doctor, Hughes continued, and he felt that he must make his family safe "while I am able." After leaving the governor, Butt reports, Taft remarked: "I don't know the man I admire more than Hughes. If ever I have the chance I shall offer him the Chief Justiceship."

Taft had not always been this enthusiastic. Less than three years earlier, he had declared himself to his brother Charles as sharing President Roosevelt's dislike for Hughes, who was "a man without

25. See 1 M. Pusey, Charles Evans Hughes 267 (1951).

26. See id.

27. See id., e.g., 174-75, 339.

28. See id. 267-68; 1 A. Butr, TaFt and Roosevelt, The INTIMate Letters of ARchile Burr 223 (1924). 
magnetism," and without sufficient regard for his obligation to the Republican Party. ${ }^{29}$ But in 1907, Taft's views were strongly colored by those of Roosevelt; they were indeed a rather simplified reflection of Roosevelt's complex distrust for Hughes. By 1910, Taft was forming a more independent judgment. He was, moreover, in political trouble in quarters where Hughes might not have been loved, but was certainly respected and accepted. Hughes was also the logical rival if there was to be a contest over Taft's renomination in 1912. To put Hughes on the Supreme Court was, therefore, to gain some credit where Taft needed it-from center and even slightly right-of-center all the way to the left of the Republican Party-and it was substantially to remove Hughes from contention for the Presidency. There is absolutely no evidence that calculations looking to the Presidential contest in 1912 motivated Taft to appoint Hughes. But the evidence is clear that the bearing of the appointment on the prospects for 1912 was in Taft's mind.

Brewer was from Kansas, and there might have been reason to think that Taft would go to the central or western states, the Seventh or Eighth Circuit, for a replacement. But when Peckham had died the year before, Taft had replaced him with Lurton of Tennessee, and had thus left New York, and its Second Circuit, the busiest and most important, unrepresented. And so New York was now a logical place to look for a candidate.

Taft no doubt flirted, however briefly, with one alternative, his Solicitor General, Lloyd W. Bowers of Minnesota. A few days after Brewer's death, Taft told Francis E. Warren, of Wyoming, a pillar of the Republican establishment in the Senate, who had come to explore the possibilities in behalf of his friend, Judge Willis Van Devanter of the Eighth Circuit Court of Appeals, that he greatly admired Bowers, but would hesitate seriously about appointing him to the Supreme Court now, when Bowers was doing so superb a job as Solicitor General, and had so many important causes pending. Warren nevertheless walked away believing that "today Bowers has the inside track." And if Bowers was not appointed now, he would nevertheless land on the Supreme Court, Warren thought, during the remaining three years of Taft's Presidential term. ${ }^{30}$ This latter conviction of Warren's was wellgrounded. Many years later, Taft recalled that he had "certainly in-

29. See 1 PRINGLE, supra note 11 , at 331.

30. F.E. Warren to Willis Van Devanter, Apr. 2, 1910, Van Devanter Papers, Library of Congress [hereinafter cited as Van Devanter Papers]. 
tended to put Lloyd Bowers on the Supreme bench and would have done so had he lived. I clinched the matter by sending word to him . . . that I intended to do so. Bowers was one of the best men I ever knew and was admirably adapted to succeed on the bench." 11 It seems clear that Van Devanter, Lamar or Pitney would in the next two years have lost out to Bowers, had Bowers lived. But he died prematurely, on September 9, 1910. And at the time of the Brerver vacancy, Taft was still holding him in reserve.

The only active candidacies that can be ascertained definitely for this vacancy were those of Van Devanter and of his senior colleague on the Eighth Circuit, Walter H. Sanborn, ${ }^{32}$ a perennial, now past the peak of whatever chances were ever his. The Van Devanter candidacy, which was also not being advanced for the very first time, was quite an active one. But it made no great headway..$^{33}$ The President's mind was set, and Hughes' name went to the Senate on April 25, 1910.

The tender of the Associate Justiceship came to Hughes in a longhand letter from Taft dated April 22, 1910.34 Taft knew very well that there were considerations which might cause Hughes to reject the offer. "I believe as strongly as possible that you are likely to be nominated and elected President some time in the future unless you go upon the Bench or make such associations at the Bar as to prevent." Moreover, in practice, Hughes could in a very short time earn enough to make his family secure for life. But perhaps Hughes preferred a judicial to a political life, and in that event he "might as well take the step now." There was no need for him to resign his governorship until October, when the Court's new term began, and he would thus be defaulting on no more than two and one-half months of the term for which he was elected. Taft hoped that the salary of a Justice, then $\$ 12,500$, would soon be raised to $\$ 17,500 .{ }^{.55}$ Finally:

The chief justiceship is soon likely to be vacant and I should never regard the practice of never promoting associate justices as one to be followed. Though, of course, this suggestion is only that

31. Taft to S. Philbrick, Nov. 25, 1927, Taft Papers.

32. Walter Henry Sanborn (1845-1928) was born in New Hampshire and held an A.B. and an A.M. from Dartmouth. After three years of teaching school, Sanborn moved to St. Paul, Minnesota, where he entered the law office of an uncle. In March 1892, following some twenty years of practice, he was appointed U.S. Circuit Judge by President Benjamin Harrison. Sanborn served until his death.

33. See C.D. Clark to Van Devanter, Apr. 30, 1910, Van Devanter Papers.

34. 1 PRINGLe, supra note 11 , at 532 .

35. Taft so proposed to Congress in December. 46 Conc. Rec. 25, 61st Cong. 8d Scss, $(1910)$. Salaries were in fact raised to $\$ 14,500$. See Judicial ANd Congressionat SAlaries 69 , SEN. Doc. No. 97, 83d Cong., 2d Sess. (1954). 
by accepting the present position you do not bar yourself from the other, should it fall vacant in my term.

Let me hear from you. I make this offer first because I know you will strengthen the bench as a lawyer and a jurist with a great power of application and second because you will strengthen the bench in the confidence of the people.

And then a postscript:

Don't misunderstand me as to the chief justiceship. I mean that if the office were now open, I should offer it to you and it is probable that if it were to become vacant during my term, I should promote you to it; but, of course, conditions change so that it would not be right for me to say by way of promise what I would do in the future. Nor, on the other hand, would I have you think that your declination now would prevent my offering you the higher post, should conditions remain as they are. ${ }^{3 B}$

Hughes accepted within two days. His reply was typewritten, but it had been copied from a draft in Hughes' hand which bears the mark of ease in composition, flowing along from beginning to end with only a very occasional correction. It is, sad to relate, solemn and selfrighteous:

My dear Mr. President,

A careful consideration of the questions raised by your offer to nominate me for the Supreme Court, to succeed Mrr. Justice Brewer, has convinced me that I should accept it. The honor of the appointment, great as it would be in any case, is especially enhanced in my estimation because it comes from you,-in view of your distinguished judicial career and initimate knowledge of the requirements of the office. So far as my personal inclinations are concerned, they lie in the direction of judicial work. My training and professional interests have been such that I should undertake this work with a personal satisfaction which no other line of effort could command in the same degree. No one could have a more profound sense of the vast responsibilities of the Supreme Court than I have and while this makes me realize the more keenly my shortcomings, it also disposes me to welcome the opportunity to devote my life to such important service. Against such a life-work, to meet the conditions of which an adjustment could be made, I should not for a moment set any prospect of money-making at the bar.

I trust that I should be able, however, to withstand any personal inclination, and not permit it to control my decision, if it were opposed to the obligations of public duty. This is the only

36. I PRINGLe, supra note 11 , at 532. 
question which has occasioned any difficulty. But reflection has re-assured me upon this point. There is no definite sphere of pullic usefulness, other than the place you offer, which would be open to me at the close of this year and my circumstances would permit me to accept. The opportunities of the future are conjectural .... Against this ... I should have on the bench a definite field of usefulness in the discharge of a function of national government of the gravest consequence to our people and to the future of our institutions.

The question seems to me to be really,-What right have $I$ to refuse this opportunity of public service ....

I confess that I know of none unless it be found in my present obligations as Governor of this State. But you point out that I need not qualify as Justice of the Supreme Court or resign as Governor until the second week of October. Until that time I can perform my full duty here. This would leave only a few weeks of my time .... I should regard a refusal to take up, at your request, the life-work solely because I should have to leave my office here in October instead of remaining until the close of December, as based on a ground too trivial to be just to you or worthy of myself.

After a review, therefore, of the entire situation in its personal and public aspects, I accept your offer. In announcing this, I should be glad to have you state, in order to avoid any misunderstanding, on the part of the public, that I shall be able to serve as Governor until the second week in October.

Your expressions regarding the Chief Justiceship are understood and most warmly appreciated. You properly reserve entire freedom with respect to this and I accept the offer you now make without wishing you to feel committed in the slightest degree. Should the vacancy occur during your term, I, in common with all our citizens, would desire you to act freely and without em. barrassment in accordance with your best judgment at that time.

Assuring you of my esteem and warm personal regard, and expressing again my deep sense of the confidence you repose and the responsibility it involves, I am

Very sincerely yours, Charles E. Hughes. ${ }^{37}$

Writing to a friend a few weeks later, Hughes indicated that he had no real taste for private practice and that the Presidency was a bird in a distant bush. "A refusal on the ground that sometime or other I might be a candidate for the Presidency, particularly in view of the record of the disappointed ambitions of so many historic worthies, would have been absurd."38

37. C.E. Hughes to Taft, Apr. 24, 1910, Hughes Papers, Library of Congress [hercinafter cited as Hughes Papers]. See also 1 Pusey, supra note 25, at 272.78.

38. Hughes to E.J. Ridgway, May 14, 1910, Hughes Papers. 
The Hughes nomination had a glowing and practically unanimous reception. Assorted Democrats, Insurgents and Progressives were pleased. ${ }^{39}$ The Chicago Tribune, which gave evidence that it had been taught its standards for judicial appointments by Theodore Roosevelt, hailed Hughes as being "in sympathy with the broad general tendencies of the American people." 10 Judge Charles F. Amidon, in admiration of Theodore Roosevelt, wrote Taft that Hughes' public experience will have "emancipated" his mind "from the purely analytical methods of the lawyer," as Marshall, Field, Bradley and Miller were emancipated. Amidon hoped that Hughes might eventually succeed to the Chief Justiceship. "I know of no one else in the country so well fitted to guide the Court and unify its decisions."11 And there was no dissent from the conservatives. William D. Guthrie, who wanted no part of emancipated judges, was also gratified. He offered Hughes "the thanks of your brethren at the New York bar that you have accepted the appointment. ...We are all confident that you will render the very greatest public service. . . ."42 In short, as Myron T. Herrick wrote the President, "I congratulate you most heartily upon . . . being able to please everybody,-I mean by that everybody worth while." 13 The only note of regret running through the general expressions of satisfaction-a note of regret sounded, for example, both by James R. Garfield and Maxwell Evarts-was that Hughes could now presumably never be President. ${ }^{44}$

Hughes was confirmed, promptly and painlessly, on May 2, 1910.45 But on July 4, well before Hughes resigned his governorship, Chief Justice Fuller died. ${ }^{46}$ Meanwhile a second vacancy also became certain, as the tragedy of Moody was drawing to a close. Rumors were circulating that Moody was mentally incapacitated. Actually, as Taft re-

39. Tilliam Jennings Bryan dissented. He knew the appointment would be popular with many good people who thought of Fughes as a reformer. But the reforming reputation rested, in Bryan's judgment, "upon a few official acts which showed him opposed to grafting and to the individual vices." Actually, Hughes was a personal friend of Rodkefeller and indebted to the bankers and to the other interests, whom he was all too villing to serve. In sum:

Governor Hughes exemplifies the individual virtues, and naturally demands honesty

in the public service; but he is a shining illustration of that peculiar type of citizen

developed in this country during the present generation-a citizen who personally opposes vice, and is a punisher of small crimes, but shows no indigmation at the larger forms of legalized robbery.

Washington Post, Apr. 26, 1910, at 2, col. 4; but see id., Apr. 26, 1910, at 1, col. 2.

40. Chicago Tribune, Apr. 26, 1910, at 6, col. 1 .

41. C.F. Amidon to Taft, Apr. 27, 1910, Taft Papers.

42. W.D. Guthrie to Hughes, Apr. 26, 1910, Hughes Papers.

43. M.T. Herrick to Taft, Apr. 28, 1910, Taft Papers.

44. M. Evarts to Hughes, Apr. 26, 1910; J.R. Garfield to Hughes, Apr. 27, 1910, Hughes Papers.

45. See 1 PUSEY, supra note 25, at 273.

46. C.E. Hughes, Biographical Notes 206, Hughes Papers. 
membered subsequently, Moody was crippled with arthritis. ${ }^{47}$ Letters written by Moody in the summer of 1910 give sufficient proof of his lucidity. He had been, however, as he wrote Justice Harlan, fourteen months on his back, and the best he could expect was "to get up a crippled man and perhaps with shattered health which would not en. able me to do a full man's work. . ."48 On June 23, 1910, at the President's instance, Congress passed a statute enabling Moody to retire with the same benefits that would have been available to him had he served ten years or attained seventy years of age..$^{40}$ On October 8 , Moody informed the President, "with inexpressible regret," that he would avail himself of the statute. There were some private reasons, however, "not in any way adversely affecting the public interest, why I should like to postpone the taking effect of my resignation for a few weeks. I therefore hereby resign my position as Associate Justice of the Supreme Court of the United States to take effect on the 20th of November next." 50 Taft replied warmly the very next day. "[M]y heart goes out to you, my dear friend and old-time associate, in the pain that the relinquishment of such an office and such duties and such opportunity to help your fellow man gives you. ... I would not ap. point your successor until the meeting of the Senate on the first Monday in December. There is not the slightest reason, therefore, why your resignation should take effect until then." 51

Quite plainly, and in the light of both the earlier and later experience of the Court, quite wisely, Taft was firmly resolved not to make recess appointments. And so, when Hughes took his seat on October 10, at the beginning of the Court's new term, it was a seven-man Court, and was to remain so for the rest of the calendar year 1910 .

Although the Court by no means suspended all business, or even all important business, for the rest of the year attention was centered on the appointments in the offing, and speculation, both in public and privately among the Justices, was rife. Justice McKenna, writing to his colleague Day on September 5, 1910, noted that the vacation was running out and work and responsibility were casting their shadows before. Then:

I repeat your question, who will share them with us? Quien sabe? I have assumed Hughes for C.J. because speculation some

47. Taft to W.I. Smith, Dec. 1, 1921, Taft Papers.

48. See J.M. Harlan to Lurton, July 8, 1910, Lurton Papers.

49. 36 Stat. 1861 (1910).

50. W.H. Moody to Taft, Oct. 3, 1910, Taft Papers.

51. Taft to W.H. Moody, Oct. 4, 1910, Taft Papers. 
time ago assigned it to him and there is no contrary prediction. But the other two? A newspaper the other day ventured a guess (it was said to have been discussed at a judicial luncheon at which the President, Holmes, and other judges were present) that [Solicitor General] Bowers would be one and that the other would go to the Eighth[Circuit]. But n'importe. They will be men of ability, no doubt, and the old duty will be on us "to stop and think" ... s2

And Justice Lurton, from Hot Springs, Virginia, also to Day, on September 7, 1910: "I suppose Hughes will sit in the middle, though I only know what the press reports. Moody's successor is not indicated. . . . Can't help but think that Roosevelt has not been loyal to Taft. ...".53

The newspapers were indeed full of Hughes. ${ }^{\text {as }}$ Both Lurton and Day voiced their expectation to Hughes himself. ${ }^{55}$ In writing to White, however, Lurton must have expressed a preference for White over Hughes. For on July 12, White, from Canada, was replying to Lurton:

My thoughts have been recurring to your kind expression as to the succession to the Chief. No aspiration on the subject has taken possession of me. On the contrary, the very gravest doubts exist in my mind as to whether I am the man for the place and whether the new responsibility, if it were tendered, would be beneficial either to the country or the Court. I say this with perfect candor and absolute directness. I know the necessity of unity and cohesion in the Court and believe we are going to be in a much better position in that respect than we have been. No one knows the need of the situation better than does the President and I have no doubt that he will deal with the situation for the best and no consideration personal to myself can possibly cause me for a moment to think otherwise. My term of service before retirement is not now so long-and I shall be happy if it be given to me to reach it doing the work which I have been trying to do for the past sixteen years. ${ }^{56}$

White was in a remarkably optimistic mood that summer. By fall, as Hughes recalled, "he was plainly out of sorts," presumably owing to impatience, since, as Hughes thought, he felt himself entitled to the place. He was silent and offish. ${ }^{57}$ But during the summer it was other-

52. J. McKenna to W.R. Day, Sept. 5, 1910, Day Papers, Library of Congress [hereinafter cited as Day Papers].

53. Lurton to Day, Sept. 7, 1910, Day Papers.

54. See, e.g., 1 PuSEY, supra note 25, at 279.

55. See Biographical Notes, supra note 46 , at $216-17$.

56. E.D. White to Lurton, July 12, 1910, Iurton Papers.

57. Biographical Notes, supra note 46 , at 216-17. 
wise with White. Returning from the funeral services for Fuller in Chicago, White wrote to his colleague Day:

To me the services were simple and appropriate and I could not resist the thought how wise was the disposition which called the Chief! The brethren all looked to me so much better than when we parted in Washington that it was very consoling. Somehow I cannot but think that with the new appointments which are to be made, we have good reason to look forward with more of hopeful equanimity to the work of the Court. ... Have written a few lines to Harlan about our doings at Chicago as I presume he must have been annoyed at not being asked to go. ${ }^{68}$

On August 29 White wrote again to Day:

I do not think I have been so well for nearly two years. . . . Yes, I share your anxiety . . . as to the two vacancies which are to be filled. If only you or Lurton could take the place of Chief what a blessing it would be for the country. I know nothing as to the intentions of the President. He sent for me to come to Beverly [Massachusetts, where Taft summered] which I was very reluctant to do but found no way to avoid. He did not in the slightest degree indicate his intention as to the vacancies! . . Somehow I do not feel so anxious as to the future of the Court as I have been in the past. Maybe I am less nervous and thus will give you less trouble in trying to keep me straight than you have had in the past. ${ }^{59}$

Simply and unsentimentally, White was relieved by the death of the aged Chief, who had been failing. But all this well-being and "hopeful equanimity," this sanguine serenity from a notorious and congenital worrier! Was it the mood of a man who sensed the coming fulfillment of ambition? In any case, it was a mood conveyed with winning in* genuousness.

Other ambitions stirred the Court that summer-some more, some less muted, some pretty well abandoned, but not without rue. In Holmes, rue predominated. On September 24 he wrote to his intimate English friend, Sir Frederick Pollock:

The vacation has been interrupted and saddened by these recurring deaths and I am content to make a new start from Washington. The President said he meant to send for me and talk about the new appointments. I know of no one whom I so want to see on our Bench as much as I did the late Solicitor General [Bowers]. As to the Chief Justiceship I am rather at a loss. I

58. E.D. White to Day, July 11, 1910, Day Papers.

59. E.D. White to Day, Aug. 29, 1910, Day Papers. 
should bet he will appoint Hughes who has given up a chance of being Republican nominee for the Presidency, but I know nothing. I think White who is next in Seniority to Harlan (too old, etc.) the ablest man likely to be thought of. I don't know whether his being a Catholic would interfere. I always have assumed absolutely that I should not be regarded as possible-they don't appoint side Judges as a rule, it would be embarrassing to skip my Seniors, and I am too old. [But these were considerations militating in considerable degree also against White.] I think I should be a better administrator than White, but he would be more politic. Also the President's inclination so far as I can judge seems to me toward a type for which I have but a limited admiration. I am afraid White has about as little chance as I. I really don't care much who is appointed, if only he is a man who can dispose of the little daily questions with promptitude and decision. Apart from that and the honor of being figurehead, the C.J. like the rest of us must depend on his intellectual power. I know of no first rate man except White.60

Harlan, apparently, was not satisfied to think of himself, between parentheses, as "too old, etc." It was clear to Hughes "that Justice Harlan desired the appointment as the crown of his judicial service; he thought that he could be appointed with the idea that it would not be long before the post could be given to a younger man." 12 It would not be a costly affair, in other words, to bestow this final honor on him. Attorney General Wickersham recalled later that word of Harlan's ambition, and of the suggestion that it could be inexpensively gratified, reached the White House. Harlan, Wickersham said, using a figure of speech virtually identical to the one embedded in Hughes' memory, wanted "the elevation as a final ornament to his judicial career." 62 And Harlan's good friend, Charles Henry Butler, the Court's Reporter of Decisions, remembered Harlan's deep disappointment when White was finally given the place. ${ }^{63}$ Harlan himself, however, wrote to Lurton that he was in the dark about the appointment and knew only what appeared in the newspapers. "The mention of my name in connection with the place has been without my knowledge or procurement. I do not suppose that I will be thought of."ot Whatever hopes he may or may not have harbored for himself, it is evident that Harlan did not favor the appointment of White, or even that of Hughes,

60. 1 Holame-Polloce Letters 170 (M. Howe ed. 1941).

61. Biographical Notes, supra note 46 , at $216-17$.

62. See 1 PRINGLE, supra note 11, at 534-35.

63. See C. Butler, A Century at the Bar of the Supreare Court of the UNtred STATES 173-75 (1942).

64. J.M. Harlan to Lurton, Sept. 12, 1910, Lurton Papers. 
though he was satisfied of the latter's "eminent fitness for the bench." On July 11, 1910, Harlan wrote to the President:

Although the question as to the vacancy caused by the death of the late Chief Justice is one of great importance to every citizen of the United States, especially to the present members of the Su* preme Court, I would not volunteer any expression of opinion as to a successor, if a former vacancy had not been heretofore the subject of some conversation between us. [Taft had consulted Harlan about the appointment of Lurton, which Harlan favored, and for which, at the President's request, he lobbied among some Senators.] I beg to make a few suggestions touching this matter.

Up to this time, there has been, I believe, only one instance of the Chief Justiceship being offered to an Associate Justice of the Court. That occurred in the case of Mr. Justice Cushing who, it was supposed, declined on the ground of infirm health. The usage referred to has, I think, no sound reason in its support. Indeed I have always thought that an Associate Justice ought, as a general rule, succeed a Chief Justice, who had died or resigned, unless, in the judgment of the President, he was disqualified for the position by advanced years, or by ill health; provided, always, he was, in character, soundness of judgment, sagacity and legal attainments equal to the place.

I beg to say that there is on the Supreme Court an Associate Justice who is equal to the Chief Justiceship, and whose appoint: ment would, I am confident, meet with general approval by the Bench and the Bar, as well as by the people at large. He was born in 1849 and is by no means too old for the place, especially when that fact is considered in connection with his experience in active, judicial life. His appearance at first might impress one with the idea that he was not very strong, physically. But President McKinley once told me that Justice Day was "as hard as a knot" and would likely reach an advanced age. You will know whether he was often absent from his post as a Circuit Judge on account of sickness. Since coming to the Supreme Bench he has not, that I can recall, missed but a few days, if any, on account of sickness. I have found him to be as represented by President McKinley. He has exhibited, on our Bench, an unusual capacity and fonclness for judicial work. He has been indefatigable in his judicial labors. Indeed, since he has been with us no member of the Court has held to his work more persistently or steadily nor done a greater amount of work than Justice Day. His opinions in my judgment will always be highly regarded. They show unusual care in preparation. They are not overrun with dicta nor with immaterial suggestions. I regard him as a first class lawyersagacious, cautious, as firm as a rock, and eminently wise in con.

65. J.M. Harlan to Lurton, July 3, 1910, Lurton Papers. 
sultation. And what has become a necessary qualification in a Chief Justice (however great his legal attainments or mental power may be), he has fine executive power and is a "man of affairs." His experience as a judge would enable him to take up the work of the Court where the late Chief Justice left it, and go right ahead without any delay or any friction whatever. He would not be under the necessity of becoming trained in details, upon the "handling" of which with ease and promptness so much depends. He is already fully informed as to the manner in which the business of the Court is transacted. My conviction is strong that, all things considered, the best interests of the country, and the efficient administration of the law, will be promoted by his selection as Chief Justice.

I have the honor to be,

Your Obedient Servant, John M. Harlan. ${ }^{c 0}$

The President acknowledged this remarkable communication, evidently in longhand, for there is a notation to that effect on Harlan's letter as preserved in Taft's files. There is no evidence, however, that Day was seriously considered, and no evidence whatever that he himself did anything to further his candidacy. But the fact of Harlan's recommendation remained a treasured memory in the Day family, and Day must either have known it was being made or learned of it shortly afterward, for little more than a year later, Harlan was dead. ${ }^{\circ}$ And so of the seven sitting Justices who convened in October 1910, only two-Lurton and McKenna-or possibly three, if one wishes to include Holmes, neither thought of themselves nor were thought of by others as being in contention for the Chief Justiceship. ${ }^{\text {"S }}$

The President, who devoted more loving care to the choice of judges than perhaps any of his predecessors or successors, had the matter much in mind. He rejected the notion of crowning Harlan's career, evidently with some heat. "I'll do no such damned thing," his Attorney General later reported him as having exclaimed at a conference of the lawyers in his Cabinet. "I won't make the position of chief justice a blue ribbon for the final years of any member of the court. I want someone who will coordinate the activities of the court and who has a reasonable expectation of serving ten or twenty years on the bench." ${ }^{69} \mathrm{He}$ considered Elihu Root and declared that he would

66. J.M. Harlan to Taft, July 11, 1910, Taft Papers.

67. Interview with Luther Day, e.g., Apr. 26, 1960.

68. Holmes remembered telling MIckenna that the two of them were the only ones "who didn't have booms going for us." Holares-Laski LeTters 846 (A. Howe ed. 1953); see also id. at $339,1227$.

69. See 1 Pringle, supra note 11, at 534. 
appoint him if he were five years younger, although Root was the same age as the eventual appointee, White. ${ }^{70} \mathrm{He}$ considered also, but perhaps less seriously, his Secretary of State, Philander C. Knox, who had been Attorney General under Roosevelt, and to whom Taft the following year tendered the place that ultimately went to Pitney.11

Edward Douglass White, ${ }^{72}$ Taft's eventual choice as Chief Justice, was born on November 3, 1845, in the village of Thibodaux, Lafourche Parish, Louisiana, the youngest of four children. His father, who died two years after the birth of Edward, was a lawyer and sugar planter, and had been governor of the state and a member of the United States House of Representatives. His mother was Catherine Siclney Lee Ringgold, of an old Maryland and Virginia family. White was educated in Jesuit schools in Louisiana and at Georgetown College. The Civil War ended his formal education, as White returned home and despite his youth joined a company of Louisiana volunteers. He snw active service, then read law under a senior member of the bar, and was admitted in 1868. He practiced law in New Orleans, and served two terms in the Louisiana Senate and a year as an Associate Justice of the state Supreme Court.

On March 4, 1891, he took office as a United States Senator, and early in 1894 he was Cleveland's fourth choice for Associate Justice of the Supreme Court, filling a vacancy created by the death of Justice Blatchford. In sixteen years as an Associate Justice, White made his mark most distinctly. He dissented ably in Pollock v. Farmers Loan of Trust Co., ${ }^{73}$ and in the Trans-Missouri Freight ${ }^{74}$ and Northern Securities $^{75}$ cases. He won recognition also for his important concurrence in the Insular Cases, ${ }^{70}$ and for his "pioneer work," as Taft later called it, in administrative law. This was Holmes' opinion of him in 1910: "His writing leaves much to be desired, but his thinking is profound, especially in the legislative direction which we don't recognize as a judicial requirement but which is so, especially in our Court, nevertheless." $7 \mathrm{~s}$

70. Id.

71. Taft to P.C. Knox, Nov. 29, 1911, P.C. Knox Papers, Library of Congress.

72. Douglass is the spelling in his will, on the oaths he signed as Associate and Chicf Justice, and the spelling followed by every volume of the U.S. Reports. Flis biographer prefers, and offers some evidence that White himself might have preferred, the sinipler spelling, but the evidence the other way seems considerably stronger. See M. KLINKIIAMEk, EDWARd DOUGlas White, Chref Justice of the United States 1, n.l (1949).

73. 157 U.S. 429 (1895).

74. 166 U.S. 290 (1897).

75. 193 U.S. 197 (1904).

76. Downes v. Bidwell, 182 U.S. 244 (1901).

77. 257 U.S. xxiv (1922); see Texas \&: Pacific Ry. Co. v. Abilene Cotton Oil Co., 204 U.S. 426 (1907).

78. 1 Holies-Pollock Letriks, supra note 60, at 170. 
White was a large, ponderous man, "with a small face in the center of a great head."79 He had, certainly in his later years, extremely heavy jowls. As he sat on the bench, one observer reported in 1911, he shaded his eyes with his hand to keep out the light, "and his bulky presence broods over the whole courtroom." At home he looked like a "jovial monk." "Put a brown cowl on him and you could well fancy him at the porter's wicket of a monastery, offering hospitality with the most genial grace. His welcome is a benediction." 80 Felix Frankfurter, many years later, recalled visiting TVhite at home on business and feeling enveloped by the presence of the Chief Justice, as though in a confessional. ${ }^{81}$ It was a kindly, but an elaborate presence. Mrs. Joseph R. Lamar remembered him as "quite early Victorian in his courtesy." 82 Brandeis placed him in more or less the same period. He "had the grand manner," Brandeis said, "and was of the eighteenth century." 83 Long a bachelor, White married Mrs. Virginia Leita Montgomery Kent, a widow, in 1894, shortly after coming to the Court. ${ }^{84}$

When White's nomination as Chief Justice went to the Senate on December 12, 1910, it was accompanied by two others. Joseph Rucker Lamar of Georgia and Willis Van Devanter of Wyoming were nominated as Associate Justices. Lamar succeeded Moody, and made the fourth Southerner on the bench, if one counts also the Kentuckian Harlan. Van Devanter succeeded White, and filled the western place that had been vacant since the death of Brewer. Massachusetts and New England, which lost Moody, remained represented, of course, by Holmes.

Among those to whom Taft gave consideration for appointment as Associate Justice were William C. Hook of Kansas, Judge of the Court of Appeals for the Eighth Circuit; ${ }^{\text {s5 }}$ TVilliam D. McHugh of Nebraska, a practicing lawryer in Omaha; Frederick W. Lehmann of Missouri, whom Taft, on December 19, made Solicitor General in succession to Bowers; Charles Nagel of Missouri, Taft's Secretary of

79. Acheson, Justice Is A Method, 12 Recond of N.Y.C.B.A. 143, 145 (1957).

80. See Marcosson, The New Supreme Court, 44 Miunsey's Miagazine, No. 6 Miarch 1911).

81. FeIIX Frankfurter Rentinisces 99-100 (H. Phillips ed. 1900).

82. C. LAMAR, THE ITFE OF JOSEPH RUCKER LAMAR 179-80 (1926).

83. Brandeis-Frankfurter Conversations (Harvard Law School Library).

84. KLINKHAMER, supre note 71 , at 40.

85. William Cather Hook (1857-1921) was born in Waynesburg, Pa. After recciving an LL.B. from St. Louis Law School in 1878, he practiced law in Kangs until 1899, when he was appointed US. District Judge there. He was promoted to the Court of Appeals in 1903, and served until his death. See 7 A.B.A.J. 552 (1921). 
Commerce and Labor, and widowed brother-in-law of Louis D. Brandeis; Senator George Sutherland of Utah; Chief Justice John B. Winslow of Wisconsin; Judge John C. Pollock of the U.S. District Court in Kansas; and Francis E. Baker of Indiana, Judge of the U.S. Circuit Court of Appeals for the Seventh Circuit. ${ }^{86}$ There was even a small movement, but no indication that it ever got very far, for Dean John H. Wigmore of Northwestern University Law School, one of the great names of American legal scholarship. The President's mind did not come to rest till shortly before his nominations actually went up. Judge Hook, as will appear, was in serious contention to the end. And as late as November 28, 1910, the President received a favorable reply from Justice White to an inquiry he had made about McHugh. McHugh was a conservative Democrat whom Cleveland had tried to put on the U.S. District Court, but for whom he had been unable to obtain Senate confirmation. White reported himself and several of his brethren, including Lurton, as having " $a$ very distinct and strong impression as to his ability. . . ."87

Considered geographically, virtually all of these candidates were in competition with Van Devanter, and none with Lamar. The President would seem to have had it in mind ever since he named Hughes to the Eighth Circuit vacancy created by Brewer's death that a western appointment was called for in any event. Fuller had been appointed from Illinois, and so the second vacancy in an Associate Justiceship, whether the President was going to create it by the elevation of White or of Hughes, also pointed westward. Yet in the end one appointment went to the South.

Very little is discoverable about the origins of the Lamar nomination. Joseph Rucker Lamar, cousin some few times removed of Lucius Quintus Cincinnatus Lamar, of Mississippi, who preceded him on the Supreme Court, was of the Southern gentry. He was born in Ruckersville, Elbert County, Georgia, on October 14, 1857. His father, trained for the bar, had become a minister of the Church of the Disciples of Christ.88 His mother, a Rucker of Ruckersville, was the daughter of a planter. Lamar attended the University of Georgia for two years, then Bethany College in West Virginia, which was the

86. See, e.g., Washington Post, Nov. 29, 1910, at 2, col. 5.

87. E.D. White to Taft, Nov. 28, 1910, Taft Papers.

88. During Lamar's boyhood, his father was pastor of the First Christian Cluurch in Augusta, where young Joseph attended a school for some years with Thomas Woodrow Wilson, son of a Presbyterian minister. The Wilsons left Augusta in 1870, and the two schoolboys were not to resume relations till they met again in Washington in 1913. 
college of the Church of the Disciples. From Bethany he took a degree in 1877, and a wife in the person of Clarinda Pendleton, the President's daughter. Lamar briefly read law at Washington and Lee University, and then in an office in Augusta, where he was admitted to the bar in 1878. Soon he was engaged in Augusta in a successful practice, chiefly corporate in character, with substantial concentration on railroads. He served two terms in the Georgia legislature and between 1893 and 1895 played a leading role in compiling the Civil Code of the state. In January 1903, Lamar was appointed an Associate Justice of the Supreme Court of Georgia, and in 1904 he was elected to a term lasting through January 1907. In March 1905, however, Lamar resigned and returned to law practice in Augusta. The confining nature of the work, his widow recalled later, had begun to tell on his health, and he was homesick for Augusta. ${ }^{89}$

The record Lamar made on the Supreme Court of Georgia is not very revealing. ${ }^{80}$ There was not much scope in the cases. And yet there is something at this stage of Lamar's career-as there was not to be in his few years as a Justice-that is barely identifiable as mildly progressive in tone and direction. He invoked the doctrine of res ipsa loquitur in favor of an injured employee of a brick company, reversing a directed verdict for the company; ${ }^{01}$ he took a dim view of stock dealings by corporate directors seeking to turn their inside knowledge to profit; 92 he held a labor union not liable in damages for urging a boycott against a merchant who resisted its demands; ${ }^{\text {i3 }}$ he recoiled from the horror of holding children under fourteen guilty of contributory negligence in a factory accident, or foreclosed from recovering because of the fellow-servant rule; ${ }^{04}$ and affirming the conviction of a white man on the testimony of a Negro he held: "It was not error to charge that the law is no respecter of persons, and that whether one of the parties interested is white and the other colored should have no weight with the jury. The caution was not improper. It had no tendency to prejudice their minds against the defendant ...."95 His opinions were generally concise, sometimes quite brief,

89. LAMAR, supra note 82, at 133-34.

90. Lamar's opinions will be found in Volumes 117-122 (1903-1905) of the Reports of the Supreme Court of Georgia.

91. Chenall v. Palmer Brick Co., 117 Ga. 106 (1903).

92. Oliver v. Oliver, 118 Ga. 362 (1903).

93. Watters \& Son v. Retail Clerks Union \#479, $120 \mathrm{Ga} .424$ (1904).

94. Canton Cotton Mills v. Edwards, 120 Ga. 447 (1904); Evans v. Josephine Mrills, 119 Ga. 448 (1904).

95. Summerford v. The State, 121 Ga. $390, \$ 91$ (1904). 
but the style sacrifices nothing of ease, even of languor. The opinions have a measure of grace, if no flash.

Lamar was a convivial man with a well-developed gift for friendship. Tall and handsome, he carried himself with the dignity of a civic leader. One decorous lock of his silver-grey hair had a tendency to fall over his broad forehead. The New York Times, in 1914, thought that he looked at once the scholar and the judge. ${ }^{.0}$ In 1910, Lamar's reputation was entirely local. ${ }^{97}$

President-elect Taft spent the late fall and early winter of 1908 in Augusta. He stayed with friends who were friends also of the Lamars, as was Taft's aide, Captain Butt, a native Augustan. The Presidentelect met and liked the Lamars. In the fall of 1909 it became known that the President was planning to return to Augusta, and Mrs. Lamar wrote Captain Butt inviting the President to stay with the Lamars. Butt replied that the President intended to call, but that he was staying with his friend, Major Joseph V. Cumming, a close friend also of the Lamars, who had been a senior associate of Lamar's in law practice. The President came in November, and the Lamars dined with him at Major Cumming's and also received a morning call from him. Rumors that Lamar was headed for the Supreme Court were by then current locally. In July 1910, Taft offered Lamar appointment to a commission that was to go to Mexico to attend the centenary of Mexican independence. Lamar was unable to go, but he replied with much praise for the President's achievements.08

Many years later, when Chief Justice, Taft recalled: "I only succeeded in securing a man such as I wanted in the South by going down South and staying there for several vacations. This enabled me to know him. I mean Lamar." quite late in 1910 that he did indeed want a man from the South. In the

96. New York Times, May 24,1914 , at 2 , col. 1 .

97. Lamar seems to have come to some slight national attention only once, when a speech he delivered in Athens, Georgia, on Memorial Day, 1902, was heard by Albert Shaw: editor of the Review of Reviews, and then published with an introduction by Shaw in New York in 1902 as a pamphlet under the title, The Private Soldier of the Confederacy. Lamar addressed himself in this speech to the question of Race, as he called it. That question, he said, had merely been modified, not solved, by the Civil War, and what it had lost in intensity it had gained in complexity. In the short period since the Emancipation Proclamation, "how impossible to expect the hereditary tendencies and influences of centuries to be reversed. . .." Then Lamar touched, as Shaw thought, "the very root of remedial policy," by recommending an agrarian paternalism. Southern whites had it responsibility to train the Negro in more effective and efficient agriculture, thus making him ready for the benefits of literacy and the ultimate duties of citizenship.

98. LAMAR, supra note 81, at 161-68; A. Butt to C.P. Lamar, Sept. 1910; J.R. Lamar to Taft, July 29, 1910, Lamar Papers, University of Georgia Library [incrcinafter cited as Lamar Papers].

99. Taft to W.G. Harding, Nov. 2, 1922, Taft Papers. 
fall of 1910, he seemed to be considering Lamar for a post on the new Commerce Court, which he was staffing at the same time. Or so he wrote, in reply to a letter recommending Lamar from retired Justice Henry Billings Brown. ${ }^{100}$ Taft had reached no definite conclusion. "I shall keep his name, however, among the eligible."101 By early December, Taft, while consulting Congressman William M. Howard of Georgia about Lamar's suitability for the Commerce Court, asked also whether Lamar measured up to the Supreme Court. The Georgia Congressional delegation, led by Senator A. O. Bacon, was assiduously recommending Lamar, although it may have taken them a while to raise their sights from the Commerce Court to the Supreme Court. Lamar himself was kept informed, and was interested, but discreetly aloof. ${ }^{102}$ By December 6-but not before then-Major Cumming in Augusta received a confidential wire: "The President requests that you will telegraph him your opinion of Lamar's qualification as lawyer for Supreme Court Justice. He knows his character and other qualifications. Please emphasize the lawyer in the man. There is favorable chance."103 Cumming's reply was measured, and hence, no doubt, the more effective:

If I were called on to construct a model for a judge, I would take Lamar as he is, only chipping off somewhat of his too painstaking search for finality of truth, which sometimes keeps him reaching out beyond the sea mark where other excellent judges would be willing to drop anchor. This characteristic, however, increases the burden but lessens not the excellence of his work.10:

Even at this late date the President was far from having made up his mind about the names he was to send to the Senate less than a week hence. Conceivably Lamar had been decided upon. But there is good indication that the Chief Justiceship was still in doubt and that no definite settlement had yet been reached on the place that finally went to Van Devanter. ${ }^{105}$

Willis Van Devanter, destined to sit on the Supreme Court for nearly twenty-seven years, was one of the most enduring achievements of the Taft administration, and quite possibly its greatest. Born in

100. Taft to H.B. Brown, Oct. 12, 1910, Taft Papers.

101. Id.

102. See infra notes 103, 104; C.D. Norton to W.C. Adamson, Dec 7, 1910, Lamar Papers.

103. A.V. Lawton to J.V. Cumming, Dec. 6, 1910, Lamar Papers.

104. J.V. Cumming to Taft, Dec. 7, 1910, Lamar Papers.

105. On Dec. 8, 1910, one newspaper guessed Hughes, Hook and Lamar. Washington Post, Dec. 8, 1910, at 4 , col. 5 . 
Marion, Indiana, on April 17, 1859, Van Devanter attended what is now DePauw University and in 1881 revieved an LL.B. from the Cincinnati Law School, of which Taft was also an alumnus. He then joined his father's law practice in Marion for three years. In July 1884, shortly after having married Dollie Burhans of Ionia, Michigan, he moved to Cheyenne, Wyoming Territory, where his brother-inlaw and later partner, John W. Lacey, had been appointed Territorial Chief Justice. Cheyenne, during Van Devanter's first year there, was in his own words "a lively, busy and substantial city with a population something in excess of 8,000. This spring's assessment shows a property valuation in the city of 7 millions." ${ }^{108}$ By the spring of 1888, Van Devanter could report to a friend on his rapid rise, on his widening professional experience, and on the flavor of the community that was shaping him:

In our office we have all the business we can attend to and it yields us a fair return for the labor expended.

The experience acquired in some of the positions I have held here has been of benefit to me. I have been the City Attorney of Cheyenne at a salary of $\$ 750$, and was a member of the Commission which prepared the revised statutes of the Territory (compensation $\$ 1,000$ ) and I was a member of the last legislative assembly, which but recently adjourned. ... As a rule, lawyers work much harder here, and get better fees accordingly. There are no really old practitioners in Wyoming, but what is lacking in experience is more than made up by constant study and application. ...

Our lawyers usually have good libraries. I have all the Reports of Ohio, New York, Michigan and Wisconsin, and the American and English railroad cases, and also a large and well selected list of text books. My partner has about the same number ... making in all a fair library.

Having no established decisions by our own Supreme Court, and having but few local precedents and established rules of decision, it is very common in important cases to cite authorities from the entire range of American Reports. ...

Money is often so invested here as to give quick and good returns, but the risk taken generally corresponds with the profits received.

The current rates of interest are from 1 to $11 / 4$ per cent per month. At points distant from the railroad, the rates are higher.

People are generally active and one must keep moving to keep up with the procession....

106. Van Devanter to L.A, Von Behren, May 2, 1885, Van Devanter Papers، 
Litigation at Cheyenne often involves very large amounts, which makes the fees here good. ... ${ }^{107}$

On August 31, 1889, the youthful Van Devanter was appointed Chief Justice of the territorial Supreme Court by President Harrison. Statehood followed in 1890, and Van Devanter was elected the state's first Chief Justice. He soon resigned, in October 1890, to resume private practice, which prospered and was varied, although it included some substantial railroad clients. He also resumed an active, if managerial rather than elective, political career. His politics were Republican, as were those of his father and of his father's family, following a more distant Whig past.

Although the Chief Justiceship of Wyoming had evidently not been satisfying, judicial office became henceforth a fixed ambition. Within a few months after his resignation as Chief Justice, Van Devanter tried unsuccessfully for appointment to the newly-created federal Circuit Court of Appeals, and in the alternative, to virtually any other available federal court. ${ }^{108} \mathrm{He}$ never sought a non-professional office and never failed to consider the bearing of an office on his chances for a judicial career.

Van Devanter's man in Washington was Francis E. Warren, ${ }^{103}$ Civil War veteran, rancher, Senator from Wyoming, a shrewd, energetic and durable Republican regular. Senator Warren's man in Wyoming, his confidante, counsel, and political manager, was Van Devanter. "It is time," Van Devanter noted in the spring of 1892, at the end of one of his long periodic reports to the Senator on Wyoming affairs, "to quietly consider the selection of a chairman of the State Republican Central Committee . . . ."110 The sentence characterizes Van Devanter's role in politics and his relation to Senator Warren. The man quietly selected was Van Devanter, and he headed the State Republican Committee for the next four years, managing three campaigns. In addition he acted as informal counsel and one-man drafting service to the state legislature, at least so long as it was under Republican control. In 1896, Van Devanter was Warren's chief

107. Van Devanter to A.A. Frazier, Apr. 9, 1888, V'an Devanter Papers.

108. See Van Devanter to F.E. Tarren, Feb. 28, 1891; F.E. Warren to Van Devanter, Mar. 1, 1891, Van Devanter Papers.

109. Francis Emroy Warren (1844-1929) fought with the 49th Volunteers of his native Massachusetts. He moved to Wyoming in 1868 and was governor of the territory by appointment of President Arthur in I885-86 and again, by appointment of President Benjamin Harrison, in 1889 . In 1890 he was elected first governor of the state, then went to the Senate the same jear for a term that ended in 1893 . He was again elected Senator in 1894 , and served until his death.

110. Van Devanter to Warren, Apr. 9, 1892, Van Devanter Papers. 
lieutenant in securing the Wyoming delegation for McKinley at the nominating convention of that year. As early as April 1896, Warren was informing Mark Hanna of Van Devanter's services. "Judge Willis Van Devanter represents the state's wishes and you can depend upon, and tie to him."111 Judge Van Devanter, Warren added, would make the best Solicitor General or even Attorney General the new administration could have.112

McKinley having been nominated, Van Devanter became Republican National Committeeman from Wyoming. When McKinley was elected (with no help from Wyoming, which went narrowly for Bryan), Van Devanter and Warren began campaigning hard for the Solicitor Generalship. But the Solicitor Generalship had been promised elsewhere, and Van Devanter at last, following an interview in Washington with Attorney General McKenna, reluctantly accepted appointment as Assistant Attorney General assigned to the Department of the Interior. ${ }^{113} \mathrm{He}$ would have preferred to be an Assistant Attorney General in the Department of Justice itself-_headquarters," as he called itwhere he thought he would have not only intrinsically more challenging work but also greater opportunity to come to the notice of the Attorney General and of other professional dignitaries, such as Supreme Court Justices. He said so to Warren, who replied, somewhat unkindly, that it was a little early to be thinking of the Supreme Court, and struck a nerve: "I haven't had the slighest iden," Van Devanter rejoined,

that I would get on the Supreme bench if I were even favored with twenty lives. The thing never crossed my mind for a moment excepting when I was deranged with my late illness. You probably wondered how I came to think of it in my delirium if I had never thought of it before, but such is the fact. . . . I realize that $I$ have a good strong ambition, and in fact $I$ am rather proud of it, because it usually has a good influence for one, but my ambition never reached the dizzy heights which might be suspected from your letter..$^{114}$

The Assistant Attorney General assigned to the Department of the Interior headed a busy office, and there is no question that Van Devan-

111. Warren to M.A. Hanna, Apr. 24, 1896; see M.A. Hanna to Van Devanter, Apr. 29, 1896, Van Devanter Papers. See L. Gould, Wyoming (1968).

112. Id.

113. Van Devanter to Warren, Jan. 18, 1897; Warren to W. Mckinley, Jan. 21, 1897; Van Devanter to Warren, Jan. 24, 25, 1897; Warren to Van Devanter, Mar. 12, 1897; Van Devanter to Warren, Apr. 5 , 1897, Van Devanter Papers.

114. Willis Van Devanter to Warren, Jan. 31, 1897; see Van Devanter to Warren, Mar. 11, 1897, Van Devanter Papers. 
ter did a superior job. When he had been in it for two years, he described it to a friend:

Every day more decisions pass over my desk than are decided by the Supreme Court of Wyoming in months. Some of them involve rights to land in the Everglades of Florida, in Alaska, and almost everywhere, including the lake front in Chicago; while others involve matters arising in the U.S. Patent Office and other bureaus of the Interior Department. Some involve the question whether the offspring of a white man and an Indian woman are white or Indian; and quite recently a question arose as to whether a statute affecting marriages between whites and Indians included marriages also between Negroes and Indians; and so it goes. One case involves a desert claim in Arizona, a homestead in Oklahoma, a timber purchase in Minnesota or cash entry in Louisiana. Thile another involves some mine in Colorado, Utah, California, or Alaska, or many thousands of acres of land under some railroad grant. There is no end to the variety of matters which come and go in quick succession. ${ }^{115}$

Van Devanter's fears that he would work unknown and without possibility of advancement proved groundless. He had sufficient contact with the regular staff in the Department of Justice, and he appeared in the Supreme Court. In the fall of 1898 he joined the faculty of the Columbian (now George Washington) University Law School, where his colleagues included Justices Harlan and Brewer, with whom Van Devanter soon developed relations of friendship and mutual respect.116 His general standing is indicated by a public boom he enjoyed in 1902 for appointment as Secretary of the Interior. McKinley had said he was reserving Van Devanter for judicial office, however, and that was what Roosevelt gave him.117 In 1903 Van Devanter was appointed to the U.S. Circuit Court of Appeals for the Eighth Gircuit. He now resigned not only his professorship at the Columbian Law School but also his post as Republican National Committeeman from Wyoming, which he had held throughout his service at the Interior Department. ${ }^{118}$ Practically from this moment on, he hoped for promotion to the Supreme Court of the United States.

Van Devanter's ambition was fixed on an eventual succession to Brewer, and he advised Warren that in the meantime guarded support

115. Van Devanter to F. Bond, Mar. 10, 1898, Van Devanter Papers.

116. Van Devanter to E.A. Slack, Sept. 26, 1898; Van Devanter to B.L. Whitman, Sept. 26, 1898, Van Devanter Papers.

117. Tarren to Van Devanter, June 13, 1901; Van Deranter to P.Ar. Chamberlain, Mar. 22, 1909; Van Devanter to Warren, Mar. 30, 1902, Van Devanter Papers.

118. Van Devanter to M.A. Hanna, Feb. 27, 1903, Van Devanter Papers. 
might be given to the candidacy of Van Devanter's senior colleague on the Eighth Circuit, Walter H. Sanborn of Minnesota, for any other seat. At Van Devanter's urging, Warren gave Sanborn such support in 1906, when Justice Brown resigned. ${ }^{119}$ The appointment went to Moody, and that was the end of any withdrawal by Van Devanter in favor of his senior colleague. Henceforth Van Devanter was an active, even relentless, Supreme Court candidate, and he had in Senator Warren the most faithful and effective spokesman imaginable. But Van Devanter's colleague Sanborn was not aware that his own ambitions were past the point of possible gratification, and so from 1906 on the two men were obvious, virtually acknowledged rivals, and relations between them were strained.

In 1907, at a time when vacancies were thought to be in the offing although none actually existed, word came to Van Devanter of inquiries made by President Roosevelt about Judge Sanborn. Roosevelt, looking ahead to future appointments, wondered whether Sanborn would not be likely to take too restricted a view of the powers of Congress under the Commerce Clause. The same word also reached Sanborn, and as a result, Van Devanter noted with something less than genuine amusement, Sanborn had experienced a change of views and had "almost grown eloquent" in describing the breadth of the Commerce Clause. ${ }^{120}$ Was Van Devanter himself affected in any way by the known requirements, so to speak, of the appointive powerrequirements, he might well have thought, that would also be those of any foreseeable successor to Roosevelt? Conceivably this is the specific manner in which the Progressive movement worked its influence on the judicial process, this is the concrete way in which Roosevelt "put the fear of God into judges," and this is the reason that, as Hughes remembered, Van Devanter was not, to begin with, the in. flexible conservative he became later. ${ }^{121}$

Van Devanter's estimate of the effect on Sanborn surely carried a touch of understandable malice. As to Van Devanter himself, the truth is that he had no distinct ideological commitments in these years. Whatever had lodged in him from Wyoming was not yet developed, and he brought no commitments from the Department of the Interior. Nor did he develop any on the Court of Appeals. No doubt, William D. Mitchell and Chief Justice Stone were right when, after Van De-

119. Van Devanter to Warren, Nov. 16, 1903, Van Devanter Papers.

120. Van Devanter to J.W. Lacey, November 14, 1907; of. E.B. Adams to Van Devanter, Oct. 5, 1907, Van Devanter Papers.

121. Biographical Notes, stpra note 46 , at $220-21$. 
vanter's death, they located the origins of his attachment to "economic freedom" and to the philosophy that the least government is the best in his experience of old Wyoming, where "men were the masters of their fate," and where "industry, character and brains earned success," the fruits of which a man was allowed freely to enjoy. In these conditions of Van Devanter's early career, whether quite realistically perceived or somewhat idealized, we may find, if anywhere, "the seeds of his judgments," as Mitchell said.122 But only a later hindsight enables us to do so.

Before he came to the Supreme Court, Van Devanter was, altogether and almost exclusively, a technician, a professional, "forceful, a brilliant and sound lawyer, adroit in politics and thoroughly loyal to his friends," as Warren said to Mark Hanna in 1896.123 His function was more to tell his friends what was feasible and how it should be done than to tell them what to do. Thus when the silver issue split Wyoming Republicans in 1897 and the Warren faction found it prudent to favor bi-metallism, Van Devanter went along, drafted a resolution on the subject, and discoursed at length to Warren on political strategy and consequences-but never on the merits of bi-metallism. ${ }^{124}$ It was some time before the ideologically committed Justice emerged alongside the skilled political and legal technician-whom, incidentally, the ideologically committed Justice was never to submerge.

At the very start of his career as a Circuit Judge, Van Devanter sat with three colleagues in the Northern Securities case, ${ }^{125}$ and evidently concurred in the judgment for the government, although for some reason he failed to sign the decree. Near the end of his tenure, he sat on the panel that gave the government its victory-which Van Devanter soon had the opportunity to help confirm-in United States v. Standard Oil Co. ${ }^{126}$ Both Theodore Roosevelt and Taft might have thought this a good anti-trust record. ${ }^{127}$ But in 1904, Van Devanter held the Sherman Act inapplicable to a resale price maintenance

122. 316 U.S. xix-xxi, suxix (1942).

123. Warren to M.A. Hanna, Apr. 24, 1896, Van Devanter Papers.

124. See Van Devanter Papers, Letter Press Books 1-8.

125. United States v. Northern Securities Co., 120 F. 721 (C.C.D. Minn. 1903), af'd, Northern Securities Co. v. United States, 193 U.S. 197 (190.4).

126. 173 F. 177 (C.C.E.D. Mo. 1909), aff'd, 221 U.S. I (1911).

127. In United States v. Union Pacific R.R., 188 F. 102 (C.C.D. Utah 1911), rev'd, 220 U.S. 61 (1912), Van Devanter was a member of a 3-judge majority that defeated, at the trial-court level, the government's effort to rescind E.H. Harriman's purchase of the Southern Pacific railroad. But this decision was not announced until well after Van Devanter had been appointed to the Supreme Court, and had taken his seat there. 
8

agreement enforced by the holder of a patent on sales of the patented article. ${ }^{128} \mathrm{He}$ was following precedent in this decision ${ }^{120}$ (as precedent might, however, have also been followed to another result in Northern Securities), and later went along on the Supreme Court in striking down resale price maintenance agreements where no patent was in. volved. ${ }^{130}$ But he also later continued to defend the position he had taken on patents. ${ }^{131}$ As a Circuit Judge, Van Devanter gave some sympathetic applications to federal statutes regulating railroads, particularly the Safety Appliance Act, of which he said in one case: "Obviously, the purpose of this statute is the protection of the lives and limbs of men, and such statutes, when the words fairly permit, are so construed as to prevent the mischief and advance the remedy." 132 Yet Van Devanter was generally harsh on plaintiffs: in the very case from which the above language is quoted, he ended up reversing a verdict against the railroad and ordered a new trial to determine whether the in. jured employee may not have assumed the risk of the accident that injured him. He was much wedded to the doctrines of contributory negligence and assumption of risk. ${ }^{133}$ Yet again, that was largely the technician speaking. The attitude can in some measure be traced to the later work of the Justice, ${ }^{134}$ but Van Devanter never became, like McReynolds and then Butler, a specialist in reversing plaintiffs' judgments under the Federal Employers' Liability Act. In short, it would

128. National Phonograph Co. v. Schlegel, 128 F. 733 (8th Gir, 1904). The case is cited with approval in Lurton's opinion in Henry v. A.B. Dick Co., 224 U.S. 1, 39 (1912), in which Van Devanter concurred (heartily, one dares say), and which was eventually over. ruled, against Van Devanter's dissent, in Motion Picture Co. v. Universal Film Co., 248 U.S. 502 (1917).

129. Bement v. National Harrow Co., 186 U.S. 70 (1902).

130. Dr. Miles Medical Co. v. Park \& Sons Co., 220 US. 373 (1911).

131. Van Devanter joined the dissenters in Bauer v. O'Donnell, 229 U.S. 1 (1913). He was with the majority in United States v. General Electric Co., 272 U.S. 476 (1920). See also note 128 supra.

132. Chicago, M. \& St. P. Ry. v. Voelker, 129 F. 522, 527 (8th Cir. 1904); see also United States v. Atchison, T. \& S.F. Ry., 163 F. 517 (1908); Great Northern Ry. v. United States, 155 F. 945 (8th Cir. 1907), aff'd, 208 U.S. 452 (1908); Union Stockyards Co. v. United States, 169 F. 404 (1909). The last mentioned opinion was later, after Van Devanter's accession, quoted with approval by Day, speaking for the Court in United States v. Union Stocl: Yard, 226 U.S. 286, 305 (1912).

133. See Musser-Sauntry Co. v. Brown, 126 F. 141, 144 (8th Cir. 1903); Chicago \& N.W. Ry. v. Andrews, 130 F. 65 (8th Cir. 1904); Chicago Great Western Ry. v. Smith, $141 \mathrm{r}$, 930 (8th Cir. 1905); St. Louis \& S.F. R.R. v. Dewees, 153 F. 56 (8th Cir. 1907); Denver City Tramway Co. v. Cobb, 164 F. 41 (8th Cir. 1908); Great Northern Ry. v. Hooker, 170 F. 164 (8th Cir. 1909); Chicago, M. \& St. P. Ry. v. Voelker, 129 F. 522 (8th Cir. 1904); Chicago Great Western Ry. v. Crotty, 141 F. 913 (8th Cir. 1905).

134. See, e.g., Texas \& Pac. Ry. v. Bigger, 239 U.S. 330 (1915) (Van Devanter, white and McReynolds dissenting); Seaboard Air Line Ry. v. Larick, 243 U.S. 572 (1917) (Van Devanter and McReynolds dissenting). But of. Flannelly v. Delaware \& H. Co., 225 U.S. 507 (1912); Chicago, Rock Island \& Pac. Ry. v. Wright, 239 U.S. 548 (1916). And it was Van Devanter who upheld the constitutionality of the Second Employers' Liability Act, in the cases of that name, 223 U.S. 1 (1912). 
have taken a brave man indeed to predict, from the opinions of the judge, the commitments of the Justice. ${ }^{136}$ All that one can identify this early was the flat, sensible style. ${ }^{130}$

In January 1909, as Taft was forming his Cabinet while resting in Augusta, there was a considerable movement to make Van Devanter Secretary of the Treasury. Philander C. Knox, prospective Secretary of State, made the proposal to Taft, and it was supported by Senators Aldrich, Hale, and Crane, whom Van Devanter had favorably impressed on a visit to Washington the previous winter. By February, many newspapers were announcing the Van Devanter appointment to the Treasury as a practical certainty. The appointment was of course not made, but as Knox and others discussed it with Taft, there was much talk also of Van Devanter's eligibility for the Supreme Court. The boom did no harm. ${ }^{137}$ In March, on what must have been virtually his first visit to the new President, Warren brought up Van

135. Van Devanter's opinions as a Circuit Judge appear in Volumes 126.185 of the Federal Reporter. His luck in being affrmed or reversed by the Supreme Court vas indifferent, on a slender statistical base. He was reversed twice and affirmed four timcs. Whitfield v. Aetna Life Ins. Co., 205 U.S. 489 (1907), reversing 144 F. 356 (8th Cir. 1900); Hunter v. Johnson, 209 U.S. 541 (1908), reversing Johnson v. Hunter, 147 F. 133 (8th Cir. 1906); Northern Lumber Co. v. O'Brien, 204 U.S. 190 (1907), affirming I39 F. 614 (8th Cir. 1905); Lawson v. U.S. Mining Co., 207 U.S. I (1907), affirming U.S. MIining Co. v. Lawson, 134 F. 769 (8th Gir. 1904); Great Northern Ry. v. United States, 208 U.S. 452 (1905), affirming 155 F. 945 (8th Cir. 1907); Stuart v. Union Pac. R.R., 227 US. 342 (1913), affirming 178 F. 753 (8th Cir. 1910). None of these direct encounters between Van Devanter and his future colleagues yields any particular insight. Of more significance is Allen v. St. Louis, Iron MIt. \& S. Ry., 230 U.S. 553 (1913), reversing 187 F. 290 (8th Cir. 1911). This was a companion case to the Minnesota Rate Cases, and Hughes was reversing a judgment by the District Court in Arkansas (Trieber, J.), holding rates set by the state to be confisentory and hence unconstitutional. But at an earlier stage of the case, Van Deianter, sitting as a trial judge, had granted the railroad a temporary injunction. In re Artiansas Railroad Rates, 163 F. 141 (C.C.E.D. Ark. 1908). Of course, the issue on a prcliminary injunction is not the same as the ultimate issue after trial. But Van Devanter in 1908 did express the opinion that the rates were clearly confiscatory. When the Allen case was decided in the Supreme Court, Van Devanter did not dissent.

136. A clash between Van Devanter and his able colleague WVilliam C. Hook, who turned out to be Van Devanter's chief rival for promotion, is worth mention, as it exemplifies a capacity on Van Devanter's part to give broad readings to criminal statutes when abhorrent behavior seemed to him to fit the punishment. Cf. Herndon v. Lowry, 301 U.S. 242, 264, 276 (1937) (Van Devanter dissenting). Demolli v. United States, 144 F. 363 (8th Cir. 1906), was a prosecution for mailing obscene matter. But the defendant was the author, not the publisher, and there was no evidence of any participation by him in the mailing, except as he might naturally have surmised that the publication would be mailed. The statute punished mailing only. Van Devanter affirmed a conviction. Hook, in a dissent that, at least from a debating point of view, got much the better of the argument, pointed out that on Van Devanter's reading, the printer, the proofreader and God knows who clese might also be held. This was no way to construe a criminal statute, Hook concluded. Van Devanter's holding is to be contrasted with the strained reading favoring the defendant that he gave another statute in United States v. Dietrich, 126 F. 676 (C.C.D. Neb. 1904).

137. P.C. Knox to Taft, Jan. 16, 1909, Taft Papers; Van Dewnter to Knox, Feb., I909; Van Devanter to J.W. Lacey, Feb. 17, 1909; Warren to Van Devanter, Feb. 22, 1909; Van Devanter to Warren, Mar. 3, 1909, Van Devanter Papers. 
Devanter's Supreme Court candidacy. ${ }^{138}$ It was not pushed when Peckham died that fall, because Van Devanter and Warren thought the geographical factor would work against them. ${ }^{139}$ But it was actively put forward when Brewer died. ${ }^{140}$ And at this time, a dramatic obstacle that almost cost Van Devanter his appointment first came into view.

There is preserved in the papers left by President Taft a memo. randum, undated but filed with papers bearing dates in late November 1909, which is marked "Efficiency" and carries this notation in the President's hand: "Put this in an envelope to contain such matters as to Supreme Court Justiceships as I do not refer to A.G. [the Attorney General]."141 The memorandum says:

There is no guaranty of efficiency in the future so certain as efficiency in the past. Delay in the decision of a case is often as disastrous as an adverse determination of it, and there are those who are of the opinion that the ability and disposition to dispose of judicial work with reasonable speed are desirable qualifications for a judicial position. ${ }^{142}$

Figures for the circuit judges are then tabulated by circuit. Then the judges of all the circuits are ranked together. Judge Sanborn of the Eighth Circuit comes out first both in total number of opinions and in annual average number. Lurton of the Sixth Gircuit is fourth. There follows a special comparison for the Eighth Circuit, which shows Sanborn to be far ahead of his colleague Van Devanter, with double Van Devanter's yearly average number of opinions and more than double Van Devanter's yearly average number of pages written-for pages, too, are taken into account. Sanborn is also shown to be well ahead of his colleague Hook, although not quite as impressively ahead of Hook as of Van Devanter. ${ }^{143}$

Conceivably the memorandum was produced in Washington. In November 1909, Taft was unsuccessfully struggling against his inclination to put his friend Lurton on the Supreme Court in place of Peckham, who had died the previous month. Taft was complaining, and heard complaints, that the Court was not disposing of its business because a majority of the Justices were sick or aging. The problem of

138. Warren to Van Devanter, Mar. 28, 1909, Van Devanter Papers.

139. Van Devanter to E.B. Adams, Nov. 5, 1909, Van Devanter Papers.

140. Van Devanter to E.B. Adams, Mar. 30, 1910; Van Devanter to W.H. Sanborn, $\Lambda$ pr. 2, 1910; Van Devanter to Warren, Apr. 7, 1910; Van Devanter to G.N. Bliss, Apr. 16, 1010, Van Devanter Papers.

141. Presidential File No. IA, Folder dated Nov. 21, 22, 1909, Taft Papcrs.

142. Id.

143. Id. 
efficiency was as much in his mind as ever. It was the only problem that made him waver in his determination to appoint Lurton, and the high standing assigned to Lurton in this memorandum must have reassured Taft. Given his frame of mind, it is entirely possible that the President had ordered the memorandum prepared, presumably by the Department of Justice. But the memorandum does not read as if it had been drafted in response to a Presidential inquiry. It has a self-starting, hortatory tone. This feature, and its special concentration on the Eighth Circuit, gave rise to the suspicion that the memorandum might be traceable to Van Devanter's Brother Sanborn. Van Devanter so traced it, when he heard of it some months later.

The memorandum was not left and forgotten in the Presidential file once the Lurton appointment had been made. On April 16, 1910, a few weeks after Brewer's death, and one week before Taft appointed Hughes, Secretary of Commerce and Labor Charles Nagel, a Van Devanter supporter, wrote Van Devanter that he was said to have produced fewer opinions than other judges in his circuit; "also that you do not participate in the hearing of cases to the proper extent."14s Nobody underestimated the value of the opinions Van Devanter did write, Nagel went on, but could Van Devanter send in some explanation that Nagel could use in his support?

Van Devanter, as we now know, would always be afflicted with "pen paralysis." In later years, he became resigned to this condition, consoling himself, no doubt, with the high regard in which his colleagues held him in spite of it.145 But in 1910, the charge of slowness seemed to him unjust and gave him "no little pain." He rose to the defense of his record. ${ }^{146}$ As to sitting at hearings in the various cities of his extremely large circuit (which comprised twelve states and one territory), he thought he sat as often as his colleagues. As to opinionwriting, Nagel's informant failed to take account of a number of important trials, criminal and civil, over which Van Devanter had presided by special assignment, and which also involved written work.

144. C. Nagel to Van Devanter, Apr. 16, 1910; see also Warren to Van Devanter, Apr. 17, 1910, Van Devanter Papers.

145. Many years later, Hughes recalled that Van Devanter "was slow in getting out his opinions-having what one of his most intimate friends in the Court fof the $19200^{\circ}$ s and 20's] (Justice Sutherland) described as 'pen paralysis.' This difficulty increased with the years, but his careful and elaborate statements in conference, with his accurate review of authorities, were of the greatest value. If these statements had been taken down stenographically, they would have served with little editing as excellent opinions. His perspicacity and common sense made him a trusted advisor in all sorts of matters. Chicf Justice White leaned heavily upon him and so did Chief Justioc Taft, especially when the latter began to fail in health." Biographical Notes, supra note 46, at 220-21.

146. Van Devanter to C. Nagel, Apr. 10, 1910, Van Devanter Papers. 
Moreover, Van Devanter pleaded, appellate opinions are not fungible quantities. They may concern a single, simple case, or a number of cases with complicated records. "And in this connection justice to myself requires me to affirm that I have not been averse to bestowing a large amount of labor upon a single case when there has been occa* sion therefor, and also to affirm that the outcome usually has justified me in so doing." Quality and accuracy, Van Devanter had assumed, were more important than quantity. Finally:

The statement [cited by Nagel] contains an implication that $I$ am indisposed to work and am inclined to shirk, when, no matter what my faults may be, that is the last one that will be ascribed to me by any one who really understands me, and whose criticism is genuine. There is nothing more which I properly can say at this time, save that while this letter is marked as personal you are at liberty to do with it as you think is right. ${ }^{147}$

In the following months Van Devanter heard from two separate sources that Taft had him under consideration, along with his colleague William G. Hook, but was worried that Van Devanter wrote fewer opinions than the other judges and was behind in his work. "Get this impression out of his mind," was the advice of Van Devanter's friend Dennis J. Flynn, the Oklahoma Delegate in Congress, who had seen Taft. ${ }^{148}$ During the summer and fall, Van Devanter explained to two of his close friends, Flynn and his colleague Judge Elmer B. Adams, another factor that had a bearing on the number of opinions he had been able to produce. Through the past winter and spring, Mrs. Van Devanter had been ill and had required an operation at the Mayo Clinic. Not unnaturally, this situation had interfered with Van Devanter's work. ${ }^{149}$

Matters came to a head in the ten days just before Taft made his appointments. On December 3, 1910, Senator Warren telegraphed Van Devanter that the President had told him that he had a list of cases decided in the Eighth Circuit, and that it looked as if Van Devanter had not done his share. ${ }^{150}$ The President seemed fairly angry and said to Warren that Van Devanter should be advised to get the other side of the case, if any, before the President. Van Devanter replied immediately with the following coded wire addressed to Warren:

147. Id.

148. D.J. Flynn to Van Devanter, June 27, 1910; see E.B. Adams to Van Devanter, August 12, 1910, Van Devanter Papers.

149. Van Devanter to D.J. Flynn, Nov. 6, 1910; Van Devanter to E.B. Adams, August 27, 1910, Van Devanter Papers.

150. Warren to Van Devanter, Dec. 3, 1910, Van Devanter Papers. 
It is true that I am now behind in Circuit Court of Appeals work but not to extent apparently represented. While this is to be regretted it does not arise from indolence or timidity in reaching conclusions, or hesitancy in giving effect to them. I may have given too much attention to closely contested and important cases, especially where there have been differences of opinion, and may have been too tenacious of my own views, but I have felt justified in my course because it almost always has resulted in unanimity and has tended to produce harmonious rules of decision. [This was certainly a point well calculated to appeal to Taft, who in later years, at least, exhibited a positive passion for massing unanimous courts.] I have done much important work in circuit [trial] courts which, if added to my appellate work, makes my total easily up to average of my associates. I emphatically protest against impressions which seem to have been created, but make no complaint of President's attitude for it is obviously reasonable. I cannot prepare and submit showing in my own behalf now without assuming attitude which would be distasteful to me. For this reason I prefer that further consideration of my name be omitted. Then at some later time when there are no appointments at stake I shall hope President will permit me personally to make full statement of my work to him and yourself. I will owe this to both because of his consideration of my name and because of your interest in presenting it. ${ }^{151}$

Warren sent a decoded copy of this telegram to the President, saying that he feared he had annoyed Taft in their interview of a few days back and expressing regret. He was now asking that the President discontinue consideration of Van Devanter's name for immediate appointment to the Supreme Court.152

Van Devanter meanwhile supplemented his telegram with an eightpage letter to Warren, ${ }^{153}$ as impassioned a document as he is known ever to have composed. Judge Sanborn had been in Washington to see the President, Van Devanter wrote, and Sanborn would not only "go a long way to accomplish his own preferment," but "would also prefer that none of his associates be appointed." 164 Sanborn had a table prepared purporting to show the number of decisions rendered by every circuit judge in the United States. It had been prepared by an old, unreliable bailiff, and no doubt formed the basis of the President's misgivings. Van Devanter then went on to elaborate the arguments in his own defense, adding that while Sanborn was ahead of anyone

151. Van Devanter to Warren, Dec. 4, 1910, Van Devanter Papers.

152. Warren to Taft, Dec. 5, 1910, Taft Papers.

155. Van Devanter to Warren, Dec. 5, 1910, Van Devanter Papers.

154. Id. 
in the number of opinions written, and while Van Devanter was currently somewhat behind, he, Van Devanter, was nevertheless not out of line with the nationwide average. On December 7, Warren wrote Van Devanter that the President had sent for him and had told him that he proposed to discuss Supreme Court appointments with his Cabinet, that an early decision could be expected, and that, for himself, he had very nearly concluded that he would appoint Judge Hook.1t5 On December 9, Warren again saw Taft, and the President said that Van Devanter's telegram had made a good impression, being a dignified paper, and that Secretary Nagel had brought before the Cabinet Van Devanter's letter to him of the previous spring, which was also thought to be dignified, as well as persuasive. The Cabinet consensus favored Van Devanter, but the President himself did not appear entirely convinced. He said he feared Senator Knute Nelson of Minnesota, although far from being an Insurgent, might oppose Van Devanter on the ground that he was a railroad lawyer. Nelson was a member of the Judiciary Committee. Would Warren see about that?

Warren did, and it turned out that Nelson thought Sanborn, not Van Devanter, was a railroad servant, and was opposed also to Frank B. Kellogg, of Minnesota, who had in any event taken himself out of the running in a letter to the President in August, because he was serving as special counsel to the government in the antitrust case against the Standard Oil Company. ${ }^{160}$ Warren told the President that he had a good letter from Van Devanter and promised to get permission to give it to the President, which he did the following day. Then Warren mounted for the President's benefit the following argument against Judge Hook. If he appointed Hook, the President would be seen as engaged in pacifying the Insurgents, because both the Hook appointment and that of Hughes would be credited to the Insurgents and against the regular Republicans. In addition, the President would be accused also of pacifying the Democrats by appointing Southernersall of which would be rather hard on the main body of the President's Republican supporters. The argument, Warren thought, seemed to go home to Taft. And Warren left in a hopeful mood. "Let me say to you," he wrote Van Devanter, "there has been a fight, what a fight, over this matter, and nine-tenths of the time you have been one of the underdogs; but there are a few of your friends who have never

155. Warren to Van Devanter, Dec. 7, 1910, Van Devanter Papers.

156. F.B. Kellogg to Taft, Aug. 12, 1910, Taft Papers. 
let go, and I now look for success unless another one of the backsliding periods comes on." 157

Judge Hook's reputation as the Insurgent candidate was manufactured by Senator Warren out of whole cloth for the specific and sufficient purpose of mobilizing regular Republican Senators to urge Taft, in the last moments, to appoint Van Devanter. On December 12, the nominations having just gone to the Senate, Warren exulted to Van Devanter: "I guess the fire I started under Hook by claiming he was the Insurgents' candidate has spread broadly." 168 It may be doubted that Taft himself was taken in, but he is likely to have heeded the Senatorial representations which Warren was able to produce.

After he made his appointments, Taft wrote to both Sanborn and Hook. To Sanborn he said, on December 15, 1910 (incidentally tending to confirm Van Devanter's allegation that it was Sanborn who had come forward with the efficiency statistics):

I took Van Devanter only after a long investigation in which I found that he had been sick and his wife had been ill, and after a full letter of explanation from him. I think perhaps the dilatory habit in respect to turning out opinions could be corrected by close association with a court that sits all the time in the same city, and where the comparison between him and the other judges will be constant, and when he knows why it is that I seriously hesitated before taking him. ${ }^{169}$

To Hook on the following day:

You know that in the selection of judges one has to make comparison ... and it is no reflection that a man does not happen to be chosen. ... I want to say to you that so far as Kansas was concerned there never was any question in my mind that you should be selected, and that really the choice settled down between you and Judge Van Devanter. Judge Sanborn was excluded because of his age. You and Judge Van Devanter, it was suggested at one time, ought to be excluded because of your participation in the Standard Oil case [both Hook and Van Devanter had sat as judges on the Eighth Gircuit Court of Appeals in deciding that case in favor of the government]. I thought about that and reached the conclusion that because a man has decided a case as he thought right in the course of his duty was no reason for his exclusion from the court in which the same case might come before him. The selection between you and the gentleman who was chosen was a very even matter, and fortune threw it to him.

157. Warren to Van Devanter, Dec. 9, 1910, Dec. 10, 1910, Van Devanter Papers.

158. Warren to Van Devanter, Dec. 12, 1910, Van Devanter Papers.

159. Taft to W.H. Sanborn, Dec. 15, 1910, Taft Papers. 
I congratulate you upon the standing that you have in the circuit and upon the fact that I became convinced that you were Supreme Court material. It did not seem wise to take two judges from the same circuit, and for that reason the choice fell as it did; but I believe it right for me to express to you my high appreciation of the spirit in which you take the choice. ${ }^{160}$

Hook's spirit was indeed commendable. He wired Van Devanter on the day of the appointments: "While my personal preference was for another, nevertheless, old man, I congratulate you."101

Warren had an explanation not only for Hook's defeat but also for Taft's choice of White over Hughes. This explanation was less Machiavellian, but also entirely Senatorial. On December 13, 1910, in a morning-after mood, Warren reported to Van Devanter, who was still in Cheyenne:

From all I can learn, they had a monkey-and-parrot time pretty much all day Sunday [December 11] - the President and his Cabinet-chewing the rag over the Chief Justice business. The papers had been full of Hughes, and I believe the President had fully made up his mind to make Hughes the Chief Justice; but there was a regular flare-back on the part of the Cabinet, and the highup lawyers from New York and elsewhere reminded the President that while Hughes' original appointment was a good stroke because of public opinion, since the hoi polloi had all become convinced that Hughes was the only man, it would not be wise, the popular cry having been settled, to make Hughes the Chief Justice and thereby alienate all the strong legal minds who know that he had never had a case before the Supreme Court, and had never had but two important matters before him-one the insurance investigation-and that he was an uncertain quantity politically and perhaps would be in jurisprudence. Of course, on the other hand, it was deemed to be pretty raw towards the Republicans, after having appointed Lurton, to then make White the Chief Justice and add Lamar or somebody from the South. But the southern Democrats, and the northern too, were red hot on the trail for having one out of the nine judges, and Bailey and Foster [Democratic Senators] and a number of others were very urgent about White. And so I think the decision was that the Insurgents, who had finally become so offensive, would receive a knock-down if neither Hughes nor Hook was appointed; but the Democrats would be right on deck to confirm and would be satisfied; and that the stalwart Republicans would prefer even a Democrat, if it were White, to Hughes. In this I think they argued wisely, for I and others would much

160. Taft to W.C. Hook, Dec. 16, 1910, Taft Papers.

161. W.C. Hook to Van Devanter, Dec. 12, 1910, Van Devanter Papers. 
prefer White to Hughes. I said to [Senator Elihu] Root yesterday: I am not feeling very bad about White's being made Chief Justice instead of Hughes. Root replied, I am very happy over it. Thite is a better Republican than Hughes. $\mathrm{He}$ is an old-fashioned Federalist and a straightforward, fair man. Nobody can vouch for Hughes' politics. So I think that the President, from the looks of things up here, has made a ten-strike in having both stalwart Democrats and Republicans stand by him and letting the rattle-inthe-box species go farrow. ${ }^{102}$

On the Sunday evening of the day-long White House debate, Hughes received a telephone call from the White House asking him to come and see the President. Within a half-hour, as Hughes was dressing to go, another call came cancelling the appointment. Perhaps Taft had wanted to notify Hughes privately of his decision, for he had surely made it by then. A Senatorial delegation had been to see the President, and while-no matter what Root told Warren-they did not openly object to Hughes as a Progressive, they did emphasize his youth, the fact, trivial as it may seem, that Hughes had never argued a case before the Supreme Court, and the awkward situation that might be created within the Court if so junior a member were named to preside over it. ${ }^{163}$ The last-mentioned point, if no other, must have impressed Taft. He probably suspected White's tacit aspiration. He knew, as the Senators may not have known and as he himself had no reason to surmise when he wrote Hughes about the Chief Justiceship in April, that Harlan wanted the crowning reward. And he knew, as the Senators certainly did not, that Harlan had recommended Day. He might have supposed that Day was aware of the recommendation and also aspired to preside; Day might therefore resent Hughes, although he would accept the senior White. There is no evidence that these were in fact Day's feelings, but Taft might fairly have thought so. ${ }^{104}$ Moreover, there were other influences working against Hughes. In a series of letters in November and early December, 1910, Amasa Thornton, a New York lawyer acquainted with both Roosevelt and Taft,

162. Warren to Van Devanter, Dec. 13, 1910, Van Devanter Papers.

163. See 1 Pusey, supra note 25, at 279-280.

164. Speaking in 1954, Felix Frankfurter recalled that the Court as a whole was opposed to the nomination of so fresh a judge as Hughes, and that all the Justices save Holmes (and, of course, Hughes) "drew up a round robin to present to Taft" and also, "I belierc," saw Taft, to inform him of their opposition to Hughes. Frankfurter gave no source for this story. His chief one would have been Holmes, but in later years, when recollection might have been uncertain. And Holmes would have been reporting the action of others, in which he did not join. He might have been privy to the expression of an intention never in fact carried out. There is no independent evidence supporting this story. F. FankEURTER, OF LAW AND MIEN 121 (P. Elman ed. 1956). 
argued with some vehemence that a Hughes appointment would alienate the Colonel. "I had a further interview with Mr. Roosevelt today," Thornton wrote on December 2. "He is very much opposed to the promotion of Justice Hughes ... and I believe if you do it that it will add perplexity to a situation that is now working out for the best. ... I know that big politics is in promoting Justice White."105 Not only would such a move fail to open another Rooseveltian wound; it would also stand a chance of capturing some Catholic votes. ${ }^{100}$ One may well believe on the basis of substantial other evidence that Thornton was not misrepresenting Roosevelt's feelings, and it is certain that in the winter of 1910 Taft still had some interest in conciliating Roosevelt, and some hope that an irrevocable breach could be avoicled. Governor Hughes had incurred Theodore Roosevelt's lasting displeasure over a patronage incident in 1907, and matters were not helped by a further misunderstanding in the summer of 1910, after Hughes had been appointed but while he was still in Albany. ${ }^{107}$

Reaction to the appointments of Hughes, White, Lamar, and Van Devanter confirmed Senator Warren's impression that the President had "made a ten-strike." The President at the same time also sent in five nominations to the newly-created Commerce Court, and two to the Interstate Commerce Commission. At a minimum, the general tone of opinion about the appointments as a whole may be characterized by the comment of the Kansas City Times, a Progressive newspaper: "Some are obviously admirable; none is obviously wrong." 108 There was much sober discussion of the long-range importance of the Supreme Court appointments. "In a qualified sense and yet to a very practical degree," The New York Sun said, "the Supreme Court is a continuous constitutional convention." Taft, it was realized, had performed one of the high functions of his office, and there was gratification that he had performed it well, as might have been expected, since Taft was himself a former judge. ${ }^{160}$ The naming of White took everyone by surprise. But it was a pleasant surprise all around, not least of all for Holmes, although he remained curiously rueful, and was led to reflect about retirement. ${ }^{170}$ White's reputation was towering. Despite

165. See Presidential Series No. 2, File 101, particularly A. Thornton to Taft, Dec. 2, 1910, Taft Papers.

166. Id.

167. See HARBaUGH, supra note 15, at 352; 3 M. SULIIVAN, OUR TMms 283.85, 288 (1030);

G. MOWRY, THEODORE ROOSEVELT AND THE PROGRESSIVE MOVEMENT 136 (1946).

168. 41 LITERARY DIGEST 1181 (Dec. 24, 1910).

169. Id. 1181-83.

170. See 1 HolmEs-Pollock LeTters, supra note 60, at 172. 
his dissent in the Northern Securities case, nobody considered him a reactionary. Even the Philadelphia North American, which had its doubts, thought that White's appointment was the best. The elevation by a Republican President of an ex-Confederate soldier to the headship of one of the three coordinate branches of the federal government was, of course, much noticed. "It seems to me," said Theodore Roosevelt, "that nothing could be a better augury of the future of the country than that a Republican President should appoint a former Confederate Chief Justice of the United States, and receive the unanimous applause of his countrymen." 171

The appointment of Lamar, also a Southern Democrat, evoked similar reactions in a minor key. The Augusta Chronicle was pleased to note that the South was "coming into her own-is taking her rightful place in the nation -and that at the hands of a Republican President, who is, himself, bigger and better than his party-indeed, good enough to be a Democrat."172 If there was a complaint about Lamar, it was that he was obscure, but then he was plainly a lawyer of standing and had judicial experience. The same was true of Van Devanter, who, it was remarked, was one of the judges who had decided the Standard Oil antitrust case in the government's favor in the Circuit Court.

But approval was not altogether unanimous. Thus the Philadelphia North American:

There is justifiable suspicion concerning Judge Van Devanter, who has participated in decisions hostile to the whole policy of railroad regulation by the federal government and indicative of undue sympathy with the railroads. And this questioning spirit among progressive men in both parties is intensified by the fact that he was urged for appointment to the Supreme bench only by the politicians of known corporation affiliations. Aside from the fact that he golfed and dined with Mr. Taft in Georgia, Judge Lamar is an unknown quantity, if not a nonentity. In Georgia men are classified as "Hoke Smith Democrats" or "Joe Brown Democrats." The former are Progressives. The latter are corporation-serving reactionaries. Concerning Judge Lamar all that is said at present is that he is not a "Hoke Smith Democrat" and that after leaving the Georgia Supreme Court he became counsel for the railroads. ${ }^{183}$

171. See 41 LITERARY Digest 1181, 1182; see also Mowry, supra note 167, at 179; Whashington Post, Dec. 13, 1910, at 6, col. 1. The gesture was neither trivial, nor uncontroversial. Joseph B. Foraker, of Ohio, then in the Senate, realled complaining to Taft on this score. The war was over, said Taft. But not for those who fought in it, Foraker replied, although he had nothing but the highest regard for White himself. Foraker also recalled that the sentiments of his old comrade, Justice Harlan, were similar, in addition to being othervise embittered as well. J. Foraker, Notrs from a BusY LIFE 404.05 (1916).

172. Augusta Chronicle, Dec. 13, 1910.

173. Philadelphia North-American, Dec. 14, 1910. 
A similar note regarding Van Devanter was struck in the Saturday Evening Post a few months later. An anonymous writer pointed out that Van Devanter owed all his appointments to the Senators from Wyoming, Warren and Clarence D. Clark, who were conservative Republicans. ${ }^{174}$ The article came to Van Devanter's attention, and he did not like it. He thought it "not in keeping with the dignity and surroundings of the office which I now hold." 175

A more poignant expression of dissent came to Van Devanter about simultaneously with the Saturday Evening Post article in two private letters from a boyhood friend, provoked by news of Van Devanter's elevation. L. D. Ratliff, formerly of Marion, Indiana, now of Salem, Oregon, had "had it in mind during my early formative days to be a great preacher . . . but my theology would not stay fixed, so I could not preach successfully and satisfactorily; and thus from me the years slipped by." It was interesting, Ratliff wrote, how from the same "early Republican setting you have become a defender of the rights of property, a member of perhaps the most capitalistic judicial body in the world, while I have become a rank Socialist clamoring for the complete overthrow of our whole economic system. ... At present in any contest between property and democracy we would expect the latter to get the worst of it. But in the coming time, when we have made our fight and won for democracy, oh, for the good old coming timel"170 And in a second letter, after Van Devanter had replied:

I see how you say you stand for the defense of every character of right that is recognized, protected or created by the laws of the land. And, theoretically, you are right, I think; but practically, as I see it, the Court is expected, and generally does represent and express the bias of the President who appoints it, (so far, at least, as regards his general philosophy of government) and the spirit of the particular ruling element which he represents. If to him the prosperity of big business is the basis of good to all the people, the men he appoints ... will be favorable to big business. . . At this time, it seems to me, this is the philosophy that is being applied to government; and so, the idea of the superior rights of property is having its inning. ... .

In all of which I am trying to say, right and things are not fixed and definite quantities in our laws and constitutions, but are the products largely of judicial rendering, and are secured and made applicable according to the bent of the Court. ${ }^{177}$

174. Saturday Evening Post, Mar. 18, 1911, at 25.

175. Van Devanter to W.A. Richards, June 2, 1911, Van Devanter Papers.

176. L.D. Ratliff to Van Devanter, Mar. 20, 1911, Van Devanter Paper's.

177. L.D. Ratliff to Van Devanter, Apr. 10, 1911, Van Devanter Papers. 
He was not of those, Ratliff had said in his first letter, "who believe the Court is divinely bent. Rather its members are men of like passions with ourselves, having feelings and motives entirely human." Van Devanter must indeed have deemed these sentiments "not in keeping with the dignity and surroundings" of his office. They were not the sort of thing he or his colleagues were likely to hear from people they knew. This was another world impinging on Van Devanter, the world of radical agitation, of the Progressives and beyond. For over a quarter of a century, the Ratliffs of this other world would go their way, and Van Devanter his, but when Van Devanter retired, it would be "the good old coming time." 